\title{
Butyrate-Mediated Genomic Changes Involved in Non-Specific Host Defenses, Matrix Remodeling and the Immune Response in the Rumen Epithelium of Cows Afflicted with Subacute Ruminal Acidosis
}

\author{
${ }^{1}$ Louis Dionissopoulos, ${ }^{1}$ Anne Hermen Laarman, ${ }^{1}$ Ousama AlZahal, \\ ${ }^{1,4}$ Sabrina Louise Greenwood, ${ }^{1}$ Michael Alexander Steele, \\ ${ }^{2}$ Jan Cees Plaizier, ${ }^{3}$ James Clyde Matthews and ${ }^{1}$ Brian William McBride \\ ${ }^{1}$ Department of Animal and Poultry Science, \\ Ontario Agricultural College, University of Guelph, Guelph ON N1G2W1, Canada \\ ${ }^{2}$ Department of Animal Science, \\ College of Agriculture and Food Sciences, University of Manitoba, Winnipeg MB R3T 2N2, Canada \\ ${ }^{3}$ Department of Animal and Food Sciences, \\ College of Agriculture, University of Kentucky, Lexington KY, 40546-0215, USA \\ ${ }^{4}$ Department of Animal Science, \\ College of Agriculture and Life Sciences, University of Vermont, Burlington VT, 05405-0148, USA
}

Received 2012-12-07, Revised 2012-12-13; Accepted 2013-01-31

\begin{abstract}
Subacute Ruminal Acidosis (SARA) is a disorder in cattle which can lead to chronic inflammation in the rumen epithelium, known as rumenitis. Butyrate has been shown to attenuate some of the detrimental effects of inflammatory gastroenteral disorders but the molecular mechanisms mediated by butyrate have not been defined. The objective of this study was to define the inflammatory-related genomic changes responsible for the beneficial effects of butyrate. Experimentally, 16 fistulated dairy cows at mid-lactation were fed a SARA-inducing (45\% non-fiber carbohydrate) diet beginning 2 days before the beginning of treatment and continuing throughout the experiment. Cows were then evenly divided into treatment groups where a carrier with $(\mathrm{n}=8)$ or without $(\mathrm{n}=8)$ supplemental butyrate $(2.5 \%$ initial DM intake) was deposited into the rumen daily for 7 days. The minimum rumen $\mathrm{pH}$ was higher in cows with supplemental butyrate $(4.96 \pm 0.09$ to $5.20 \pm 0.05, \mathrm{p}=0.040)$, but mean $\mathrm{pH}$, maximum $\mathrm{pH}$ and the duration for which rumen $\mathrm{pH}$ was below 5.6 was unaffected. Free plasma Lipopolysaccharide (LPS) concentration was unaffected by treatment as was the concentration of Serum Amyloid A (SAA), although the LPS Binding Protein (LBP) concentration was increased by the addition of butyrate to the rumen $\left(6.91 \pm 0.29\right.$ to $\left.7.93 \pm 0.29 \mu \mathrm{g} \mathrm{mL}^{-1}, \mathrm{p}=0.024\right)$. Of the rumen Short Chain Fatty Acids (SCFA) tested, only butyrate showed a pronounced treatment effect, rising from $8.60 \pm 0.94$ to $21.60 \pm 0.94 \mathrm{mM}(\mathrm{p} \leq 0.0001)$. Plasma Beta-Hydroxybutyrate (BHBA) concentration also increased (799.50 \pm 265.24 to $3261.63 \pm 265.24 \mu \mathrm{M}, \mathrm{p} \leq 0.001$ ). Butyrate infusion did not affect milk parameters (total fat, lactose, total protein and LOS); however, when related to dry matter intake, milk production efficiency was increased $(p=0.035)$. Microarray and qRT-PCR analyses of rumen papillae biopsies collected on day 7 found that butyrate administration affected $(p \leq 0.05)$ the expression of genes involved in Non-Specific Host Defense (NSHD), Remodeling or adaptation (RM) and Immune Response (IR). Of the 49 genes tested by qRT-PCR, 9 (LCN2, MMP1, MUC16, GPX2, CSTA, FUT1, SERPINE2, BCAM, RAC3) were upregulated, 20 (MTOR, AKIRIN2, NFKBIZ, NFKB2, ACVR2A, LAMB1, FRS2, PPARD, LBP, NEDD4L, SGK1, DEDD2, MAP3K8, PARD6B, PLIN2, ADA, HPGD, FMO5, BMP6, TCHH) were downregulated and 20 were unchanged due to butyrate administration in the proximal gastrointestinal tract.
\end{abstract}

Corresponding Author: Brian William McBride, Department of Animal and Poultry Science, University of Guelph, Guelph, ON N1G 2W1, Canada 


\begin{abstract}
These results demonstrate the potential protective effect and molecular mechanisms involved in a novel butyrate
\end{abstract} treatment for inflammatory gastrointestinal conditions.

Keywords: Butyrate, Epithelium, SARA, Inflammation, Rumen, Wound Healing, Gene Expression

\section{INTRODUCTION}

SARA is a chronic pathological inflammatory condition of the rumen, affecting approximately $20 \%$ of all dairy cattle in North America (Garrett et al., 1999). Although attempts to define the etiology of SARA have gained headway in the past 10 years, its precise mechanisms remain uncertain. Due primarily to the microbial fermentation to SCFA of soluble starch of high grain diets, SARA can lead to liver abscesses, laminitis and acute inflammation of the rumen epithelium (Kleen et al., 2003; Plaizier et al., 2008). SARA does this by causing a sloughing of the rumen epithelium, compromising epithelial integrity (Steele et al., 2011a). Despite the fact that the transmigration of microbes across the rumen wall has been documented in cases of SARA, we have shown that this effect involves the immune system, although the extent of immune system stimulation is limited to local events and is not detectable systemically (Dionissopoulos et al., 2012a; 2012b). Experimentally, we have shown that adaptation to a SARA diet takes place within three weeks (Steele et al., 2011a) and previous experiments have shown that one of the principle methods by which the rumen adapts to an acidotic diet is by increasing papillae size and thus the total absorptive surface area of the rumen (Gabel et al., 2002), by increasing cellular turnover and an overall increase in total epithelial cell number (Goodlad, 1981).

There is strong evidence to support the involvement of butyrate in both normal and pathological conditions of the Gastrointestinal Tract (GIT) in both humans and experimental animals (Guilloteau et al., 2010). Roediger (1990), found a direct correlation between the severity of ulcerative colitis and the levels of butyrate. Since butyrate has been previously shown to be an important energy source for the GIT (Ahmad et al., 2000), we can speculate that low butyrate levels likely lead to an energy-deficient state (low ATP) and low metabolic rate in the rumen. These effects may culminate in the promotion of apoptosis and hence the degradation of the epithelial barrier. Indeed, butyrate can directly stimulate epithelial cell proliferation and differentiation (Aoyama et al., 2010; Zhang et al., 2010), both events which are hallmarks of the healing and restoration of normal function following an immunological insult. The ability to reduce or modulate the severity of the immune response is critical to our understanding of how sub-acute inflammatory conditions such as SARA exert their negative effects. A reduction in the duration and the extent of the immune response can have beneficial effects since nutrient partitioning favouring immune cell recruitment and growth can be limited (Dionissopoulos et al., 2006). In addition, reductions in the magnitude and severity of the immune response have been shown to favour wound healing and remodelling following injury (Eming et al., 2007). Since the reduction of pro-inflammatory cytokines such as IL-1 $\beta$, IL6 and TNF- $\alpha$ can reduce the length and severity of the immune response (Johnson, 1997), it follows that limiting such a response with naturally occurring substances in subclinical disease can have beneficial effects.

An understanding of the molecular mechanisms involved in rumen epithelial remodelling in sub-clinical disease would be incomplete without an exploration of inflammatory events at the gene expression level. The question that invariably arises centers around the principle effectors or transcription factors that mediate the immune cascade, which are known to be nuclear factor $\kappa \mathrm{B}$ (NF$\kappa \mathrm{B} / \mathrm{p} 50 / \mathrm{p} 65)$ and Peroxisome Proliferator Activated Receptor types (PPARs) in such a setting (Hoffmann and Baltimore, 2006; Calder, 2008). NF- $\kappa B$, originally studied as a promoter of lymphocyte maturation (Kumar et al., 2004), has been found to have a much broader scope of action. NF- $\mathrm{kB}$ is found to be present in promoter sequences of pro-inflammatory cytokines, the inflammatory enzyme COX-2 and in leukocyte adhesion molecules (Sigal, 2006; Perkins 2007). Because of its importance, it can be seen how NF-kB and its cofactors will likely be targets for future immunomodulatory agents such as butyrate (Jobin and Sartor, 2000a; 2000b; Kinoshita et al., 2002; Zhang et al., 2006). Briefly, stimulation by bacterial or viral antigens, cytokines and Reactive Oxygen Species (ROS), IKK (an NF- $\kappa \mathrm{B}$ kinase) phosphorylates the inhibitory subunit of the $\mathrm{NF}-\kappa \mathrm{B}$ complex, I $\kappa \mathrm{B} \alpha$, prompting its dissociation from the p50/p65 NF- $\kappa B$ complex. Once free of its inhibitory complex, NF- $\kappa \mathrm{B}$ traverses the nuclear envelope and begins the inflammatory cascade (Hoffmann and Baltimore, 2006).

PPARs are also important transcription factors in gastrointestinal inflammation. However, their effects are thought to act in an opposing manner to that of NF- $\kappa \mathrm{B}$ as anti-inflammatory agents (Guri et al., 2010). Most evidence of the anti-inflammatory effect of PPARs comes from studies where subjects with advanced inflammatory bowel diseases generally show decreased levels of PPAR- $\gamma$ mRNA expression (Desreumaux et al., 1999). More strikingly, in experimental mouse models, treatment with a PPAR- $\gamma$ agonist reduced symptoms of 
colitis (Desreumaux et al., 2001). Moreover, butyrate has been shown to stimulate the production of PPAR- $\gamma$ in cell lines (Kinoshita et al., 2002). Perhaps most importantly is the suggestion that PPAR- $\gamma$ inhibits NF- $\mathrm{KB}$ activation by interfering with the phosphorylation of $\mathrm{I} \kappa \mathrm{B}$, preventing its degradation and the subsequent translocation of the NF- $\kappa \mathrm{B}$ complex to the nucleus (Ross et al., 1999; Haegeman, 2003; Berghe et al., 2003).

We hypothesize that the addition of exogenous butyrate in cows afflicted with SARA will lessen the extent of immune system stimulation, will help the rumen adapt to a high grain/high energy diet and through adaptation, support changes to an epithelial barrier that is more resistant to insult or injury by pathogenic organisms to meet new metabolic demands. The goal of the experimentation described in this article is to characterize the mechanisms involved in rumen epithelial remodelling and, through butyrate supplementation, lessen the severity and extent of the negative effects of SARA. Here we outline the data relating the Immune Response (IR), rumen epithelial Remodelling (RM) and Non-Specific Host Defence (NSHD) in SARA cows supplemented with butyrate.

\section{MATERIALS AND METHODS}

\subsection{Animals, Treatments and Diet}

Sixteen mid-lactation, rumen cannulated (Duffield, 1999) primiparous and multiparous Holstein cows on a mid-lactation Total Mixed Ration (TMR) diet were selected and blocked by Days In Milk (DIM). Prior to the experiment, total Dry Matter Intake (DMI) and milk production were recorded for 7 days. Two days before the start of the study, a concentrate mix was added to the TMR to increase the Non-Fiber Carbohydrate (NFC) to $45.0 \%$ in 2 equal increments. According to previously published results, a NFC of $45 \%$ would be sufficient to induce SARA in this study (Steele et al., 2012). Each increment was $50 \%$ of the total amount of concentrate needed to increase the NFC to $45.0 \%$. The composition of the diet is presented in Table 1.

At the start of the 7-day experiment, each cow was randomly assigned to one of two treatments. Butyrate cows $(\mathrm{n}=8)$ received a ruminal dosing of butyrate (Proformix $^{\mathrm{TM}}$, Probiotech Inc., Saint-Hyacinthe, QC) while Control cows received no supplemental butyrate but did receive carrier. The butyrate powder $(50 \%$ butyric acid, sodium bicarbonate, lime) was dosed at a rate of $2.5 \%$ of pre-trial DMI, at 10.00 and $13.30 \mathrm{~h}$ daily, to coincide with regular daily feeding times.
Table 1. Diet fed to lactating Holstein dairy cows with or without supplemental butyrate

\begin{tabular}{lc}
\hline Ingredient & $\% \mathrm{DM}$ \\
\hline Corn silage & 22.9 \\
Haylage, 1st cut & 22.9 \\
Straw & 5.1 \\
High moisture corn & 16.7 \\
Protein supplement & 15.8 \\
Grain supplement & 16.4 \\
Barley grain & 60.0 \\
Corn grain & 20.0 \\
Wheat grain & 20.0 \\
Formulated (Calculated) Analysis & \\
DM, \% & 52.6 \\
CP, \% of DM & 15.9 \\
EE, \% of DM & 3.4 \\
Starch, \% of DM & 24.5 \\
NDF, \% of DM & 33.7 \\
Forage NDF, \%NDF & 75.2 \\
NFC, \% of DM & 44.0 \\
\hline
\end{tabular}

\subsection{Rumen SCFA, LPS and pH}

Rumen fluid was collected approximately $3 \mathrm{~h}$ after the afternoon feeding from the ventral sac and squeezed through 4 layers of cheesecloth and frozen for analysis of total SCFA by gas chromatography (Steele et al., 2012). Another sample of rumen fluid was analyzed fresh for total free LPS using the chromogenic Limulus amoebocyte lysate end-point assay (Lonza Group LTD., Basel, Switzerland) as previously described (Gozho et al., 2005; Dionissopoulos, 2012b). Rumen $\mathrm{pH}$ was recorded continuously for the last two days of the trial using a $\mathrm{pH}$ recording system and protocols established by our laboratory (AlZahal et al., 2007).

\subsection{Plasma BHBA, LBP and SAA}

On days 1 and 7, blood was sampled through the tailhead at $16.30 \mathrm{~h}$. After collection, the blood was stored on ice and subsequently spun at $3000 \times \mathrm{g}$, then stored at $-20^{\circ} \mathrm{C}$ until further processing. Plasma LBP was assayed according to established protocols (Khafipour et al., 2009b). Plasma BHBA was determined by the Animal Health Laboratory (AHL, University of Guelph, Guelph, Ontario) using the method of Williamson et al. (1962). Serum Amyloid A (SAA) protein levels were determined by enzyme-linked immuno assay using a multi-species SAA kit (TriDelta Development, Ltd, Maynooth, County Kildare, Ireland).

\subsection{Dry Matter Intake (DMI), Daily Milk Production and Milk Component Analysis}

DMI and milk production was calculated daily for each cow on the study. All cows were milked at $05.30 \mathrm{~h}$ 
and $16.00 \mathrm{~h}$ daily and their milk production numbers were pooled to establish a total daily milk production value. Milk protein and fat were determined spectroscopically by the CanWest DHI Laboratory (Guelph, Ontario). These values were compiled to yield an average weekly DMI, production value and milk component analysis.

\subsection{Rumen Papillae Biopsies for Microarray and qRT-PCR}

Rumen papillae were harvested from the rumen ventral sac at the end of experimental day 7 (Steele et al., 2012). Briefly, the rumen contents were partially evacuated to help access and retraction of the rumen ventral sac.

Table 2. Primer design for qRT-PCR analysis. Primer efficiency was calculated using the formula $E=-1+10(-1 /$ slope $) \times 100$; the slope was derived from the PCR 5-point standard curve $\left(\mathrm{R}^{2} \geq 0.99\right)$

\begin{tabular}{|c|c|c|c|c|}
\hline Accession \# & Gene Name & & $5^{\prime} \rightarrow 3^{\prime}$ & Efficiency $(\%)$ \\
\hline \multirow[t]{2}{*}{$\overline{N M \_174227}$} & \multirow[t]{2}{*}{ ACVR2A } & $\mathrm{F}$ & GGTTGTTGGCTGGATGAT & \multirow[t]{2}{*}{86} \\
\hline & & $\mathrm{R}$ & GGCTTAGGAGTTACTGGATT & \\
\hline \multirow[t]{2}{*}{ NM_173887 } & \multirow[t]{2}{*}{$\mathrm{ADA}$} & $\mathrm{F}$ & ACCAGATGACCAAGAATGAA & \multirow[t]{2}{*}{88} \\
\hline & & $\mathrm{R}$ & CACCAGAGGAGGAGGAAT & \\
\hline \multirow[t]{2}{*}{ NM_001110087 } & \multirow[t]{2}{*}{ AKIRIN2 } & $\mathrm{F}$ & CCTTGTTCCTTGTTGAGTTG & \multirow[t]{2}{*}{82} \\
\hline & & $\mathrm{R}$ & GGTTGCTGCCTAAGAGTG & \\
\hline \multirow[t]{2}{*}{ NM_174741 } & \multirow[t]{2}{*}{ BCAM } & $\mathrm{F}$ & TCTTGAGGGGAACTTGACGC & \multirow[t]{2}{*}{94} \\
\hline & & $\mathrm{R}$ & GGTTGTGCTGTTGTGCAGAG & \\
\hline \multirow[t]{2}{*}{ XM_002697620 } & \multirow[t]{2}{*}{ BMP6 } & $\mathrm{F}$ & GCCAGCGACACCACAAAGA & \multirow[t]{2}{*}{91} \\
\hline & & $\mathrm{R}$ & CGCCTCACCCTCAGGAATC & \\
\hline \multirow[t]{2}{*}{ NM_174008 } & \multirow[t]{2}{*}{ CD14 } & $\mathrm{F}$ & GAGGCTCTGAGAATCTACTG & \multirow[t]{2}{*}{85} \\
\hline & & $\mathrm{R}$ & CGGCAACCATACACTGAA & \\
\hline \multirow[t]{2}{*}{ NM_001166511 } & \multirow[t]{2}{*}{ COL4A1 } & $\mathrm{F}$ & ACGCGAACGCTTACAGCTTT & \multirow[t]{2}{*}{94} \\
\hline & & $\mathrm{R}$ & CGTGGGCTTCTTGAACATCTC & \\
\hline \multirow[t]{2}{*}{ NM_001167824 } & \multirow[t]{2}{*}{ CSTA } & $\mathrm{F}$ & CTCAAGTGGTTGCTGGAA & 81 \\
\hline & & $\mathrm{R}$ & TAGGAACACGCTGCTAGA & \\
\hline NM 001076017 & DEDD2 & $\mathrm{F}$ & CAGACCCTCCCACAGGATGT & 54 \\
\hline & & $\mathrm{R}$ & GGAGGCTGGGAAGGAAACTC & \\
\hline NM_001193131 & FGF7 & $\mathrm{F}$ & GAAGGAGGAGATATAAGAGTGA & 98 \\
\hline & & $\mathrm{R}$ & AGGTTATTGCCATAGGAAGA & \\
\hline NM_001101304 & FMO5 & $\mathrm{F}$ & TCGTGTAGGAGACTATGGAT & 84 \\
\hline & & $\mathrm{R}$ & TATTGTTGGATGCTGACTGA & \\
\hline NM_001163778 & FN1 & $\mathrm{F}$ & GAAGGCAGCGGACGTATCAC & 100 \\
\hline & & $\mathrm{R}$ & TCCCCCGGTTGTCCTTCT & \\
\hline ENSBTAT00000025495 & FRS2 & $\mathrm{F}$ & CCCCATCCCТАCTTCCTCGT & 93 \\
\hline & & $\mathrm{R}$ & AATGTGGCACACTGGTGACT & \\
\hline NM 177499 & FUT1 & $\mathrm{F}$ & AGACCGTAGCCGGGTGAGAT & 104 \\
\hline & & $\mathrm{R}$ & TTCATCGGTGTGCCTGACA & \\
\hline NM_001163139 & GPX2 & $\mathrm{F}$ & TGCCAAGTCCTTCTACGA & 74 \\
\hline & & $\mathrm{R}$ & CTCATTCTGACCATTCACATC & \\
\hline NM_001034419 & HPGD & $\mathrm{F}$ & ACCTCATTCTGCCTGCTA & 88 \\
\hline & & $\mathrm{R}$ & ССТCATATTCAАТССАСТССТ & \\
\hline NM_001102300 & IGFBP7 & $\mathrm{F}$ & GCGAGCAAGGTCCTTCCA & 100 \\
\hline & & $\mathrm{R}$ & GGGCACCAGTGACATTCCA & \\
\hline NM 174088 & IL10 & $\mathrm{F}$ & GGCGGTGGAGAAGGTGAA & 100 \\
\hline & & $\mathrm{R}$ & GGCTTTGTAGACACCCCTCTCTT & \\
\hline XM_002691608 & LAMB1 & $\mathrm{F}$ & CCGGCTCAACACGTTTGG & 100 \\
\hline & & $\mathrm{R}$ & GAAATCCGACACGGCGTAGTA & \\
\hline NM_001038674 & LBP & $\mathrm{F}$ & TGACGTGATTCCGCCTGAT & 95 \\
\hline & & $\mathrm{R}$ & AAGGCGCGGAAGGACTTG & \\
\hline XM_002691670 & LCN2 & $\mathrm{F}$ & GATGACCTCTGTGACTACTG & 83 \\
\hline & & $\mathrm{R}$ & TGGCGAAGTTGATGAAGTT & \\
\hline NM_001046517 & LY96 & $\mathrm{F}$ & CGTGGAATACTCTATCTCTACT & 86 \\
\hline & & $\mathrm{R}$ & CCTCGATGGCTTCTGTAAT & \\
\hline NM_001099071 & MAP3K8 & $\mathrm{F}$ & GCCGACCTCAAGAATCTG & 91 \\
\hline & & $\mathrm{R}$ & TCCTTCACCTGCTTCCAT & \\
\hline
\end{tabular}


Tabe 2. Continued

\begin{tabular}{|c|c|c|c|c|}
\hline \multirow[t]{2}{*}{ NM_001033608 } & \multirow[t]{2}{*}{ MIF } & $\mathrm{F}$ & GGATCTACATCAACTTCTGCGACAT & \multirow[t]{2}{*}{88} \\
\hline & & $\mathrm{R}$ & GAAGGTGGAGCCGTTCCA & \\
\hline \multirow[t]{2}{*}{ NM_001035411 } & \multirow[t]{2}{*}{ MLST8 } & $\mathrm{F}$ & AGCGAATCTTCCAGGTGAA & \multirow[t]{2}{*}{86} \\
\hline & & $\mathrm{R}$ & GCGGTGACGATGTATTGC & \\
\hline \multirow[t]{2}{*}{ NM_174112 } & \multirow[t]{2}{*}{ MMP1 } & $\mathrm{F}$ & GACGTGGCTCCGTTTGTTCT & \multirow[t]{2}{*}{96} \\
\hline & & $\mathrm{R}$ & TCCTGTAGGTCAGGTTTGTGTTCTC & \\
\hline \multirow[t]{2}{*}{ ENSBTAT00000020386 } & \multirow[t]{2}{*}{ MTOR } & $\mathrm{F}$ & CATTGAGCAGATTGTGGTAG & \multirow[t]{2}{*}{93} \\
\hline & & $\mathrm{R}$ & AGAGGCATAGTCCGTGAA & \\
\hline \multirow[t]{2}{*}{ FN600737 } & \multirow[t]{2}{*}{ MUC16 } & $\mathrm{F}$ & TGGACAGTAACAGCCTCTA & \multirow[t]{2}{*}{86} \\
\hline & & $\mathrm{R}$ & GTTGGTGATGGTGAAGTTG & \\
\hline \multirow[t]{2}{*}{ ENSBTAT00000018334 } & \multirow[t]{2}{*}{ NEDD4L } & $\mathrm{F}$ & GCTGATGGACGCCGAGAA & \multirow[t]{2}{*}{89} \\
\hline & & $\mathrm{R}$ & GGACGTCCCTGTGACAAACTG & \\
\hline \multirow[t]{2}{*}{ NM_001076409 } & \multirow[t]{2}{*}{ NFKB1 } & $\mathrm{F}$ & CGAATGACAGATGCCTGTATACG & \multirow[t]{2}{*}{89} \\
\hline & & $\mathrm{R}$ & CTGCAAATAGGCAAGATCAGGAT & \\
\hline \multirow[t]{2}{*}{ NM_001102101 } & \multirow[t]{2}{*}{ NFKB2 } & $\mathrm{F}$ & CCAAGGAACTGAAGAAGGT & 83 \\
\hline & & $\mathrm{R}$ & CCAGAGGATAATAGGTGAACT & \\
\hline NM_174726 & NFKBIZ & $\mathrm{F}$ & TGGACTTGGAGGCAACTAACTATG & 98 \\
\hline & & $\mathrm{R}$ & TATGGGCCAAGACTGCACAGT & \\
\hline NM_001098104 & PARD6B & $\mathrm{F}$ & CGCAGGTAGAGCTCAGTTTCG & 92 \\
\hline & & $\mathrm{R}$ & CTTCGTTGGCAGGGATGAA & \\
\hline NM_001017953 & PDGFB & $\mathrm{F}$ & AGTGGTCAGACAGGAGTAA & 68 \\
\hline & & $\mathrm{R}$ & GCAGAAGAAGGTGGATAGG & \\
\hline NM_173980 & PLIN2 & $\mathrm{F}$ & GTGGTCAGAGCCTGTCCAGAA & 98 \\
\hline & & $\mathrm{R}$ & GCAAAAGCATGAGGCCATAAA & \\
\hline NM_001083636 & PPARD & $\mathrm{F}$ & AATGTGAGCGGATCTGCAAAA & 97 \\
\hline & & $\mathrm{R}$ & GCGGCAGTACTGGCACTTG & \\
\hline NM_001105323 & PTGS1 & $\mathrm{F}$ & CCCCAAATGAGACCCTGGAT & 96 \\
\hline & & $\mathrm{R}$ & CAACCATTGGCCTGGAGAA & \\
\hline NM_174445 & PTGS2 & $\mathrm{F}$ & AATCTTCCAGTCGCAGTAG & 103 \\
\hline & & $\mathrm{R}$ & TTGAGGCAGTGTTGATGAT & \\
\hline NM_001099179 & RAC3 & $\mathrm{F}$ & GCGAATGTGATGGTGGAT & 83 \\
\hline & & $\mathrm{R}$ & GGAGAAGCAGATCAGGAAG & \\
\hline NM_174669 & SERPINE2 & $\mathrm{F}$ & CCCCCAGTGGCCTATGGT & 96 \\
\hline & & $\mathrm{R}$ & TGATGCTTTCGCCGTGGTA & \\
\hline NM_001102033 & SGK1 & $\mathrm{F}$ & TTCTCCTGGCAAGACACAA & 83 \\
\hline & & $\mathrm{R}$ & ACATTCCGCTCCGACATAA & \\
\hline NM_001076223 & SMAD1 & $\mathrm{F}$ & ATTGGAATGCTGCGAGTT & 85 \\
\hline & & $\mathrm{R}$ & GCTGTGCTGAGGATTGTAT & \\
\hline ENSBTAT00000008311 & STAT6 & $\mathrm{F}$ & GAGCCTGATGGAACCTTC & 82 \\
\hline & & $\mathrm{R}$ & AAGTGAGCGAATGGACAG & \\
\hline BC151676 & TCHH & $\mathrm{F}$ & ATGTCTGCTGTAGTCTGTAG & 81 \\
\hline & & $\mathrm{R}$ & ATGTCTCCAAGGTAGTATCAG & \\
\hline NM_001035313 & TGFB1I1 & $\mathrm{F}$ & TTCCGTGTCCAGAACCAT & 84 \\
\hline & & $\mathrm{R}$ & AGGCAGTAACCATCTTGTG & \\
\hline NM_174198 & TLR4 & $\mathrm{F}$ & CTAAGGAGCAAGAACTACAGA & 70 \\
\hline & & $\mathrm{R}$ & CAAGAAGCATCAGGTGGAA & \\
\hline NM_001101306 & TNFRSF6B & $\mathrm{F}$ & GCACCCTTCCTGGTATTTATTCA & 106 \\
\hline & & $\mathrm{R}$ & TTCCGAAGCCTCCTTTGGT & \\
\hline
\end{tabular}


Approximately $150 \mathrm{mg}$ of papillae was cut from the rumen and washed 20 times in ice-cold PBS, then placed in a stabilization agent (RNAlater ${ }^{\mathrm{TM}}$, Qiagen, Hilden, $\mathrm{GmbH}$ ) until the RNA could be isolated. Total RNA was isolated as previously described by Steele et al. (2012) using an RNeasy midi kit (Qiagen, Mississauga, Ontario, Canada). The concentration of RNA was determined using a NanoDrop (ND-1000, NanoDrop Technologies, Wilmington DE). To enhance the purity of the RNA, it was treated with DNase (Invitrogen, Burlington, Ontario, Canada) and its quality was determined using an Agilent 2100 Bioanalyzer (Agilent Technologies Inc., Palo Alto, CA and the RNA 6000 Nano kit (Caliper Life Sciences, Mountain View, CA). The RNA was then prepared for either microarray analysis, to determine the global expression pattern of genes, or for qRT-PCR, to confirm the relative expression of any genes (Steele et al., 2011b) involved in epithelial RM, the IR, or the NSHD. Where possible, primers were designed to span exon-exon junctions using NCBI/PrimerBLAST Primer Express (http://www.ncbi.nlm.nih.gov/tools/primer-blast/) and were verified as specific to the bovine genome using GenBank (National Center for Biotechnology Information, Bethesda, MD). All primer amplicons were confirmed by BLASTN in NCBI, as well as through the generation of dissociation curves to support the fidelity of single product amplification (Steele et al., 2011a), using GAPDH as the housekeeping gene. The stability of GAPDH amplicons were confirmed by low variance $($ mean $\mathrm{Ct}=20.85$; variance $=0.10)$. Primer information including sequences can be found in Table 2. Any treatment imposed differences in mRNA expression was determined using the inverse of qPCR efficiency raised to Delta Ct (Pfaffl et al., 2004). The expression values of the Control cows were pooled and expression differences were determined through the comparison of individual Butyrate group values to this index as described previously using a Student's t-test (Xue et al., 2010). Finally, all differentially expressed genes were subjected to analysis with the Ingenuity Pathway Analysis (IPA) tool (Ingenuity, Inc., Redwood City, CA) in cooperation with the University of Kentucky (Lexington, KY). The methodologies employed herein have been previously published (Steele et al., 2011b). It is important to note however that to determine the significance of differentially expressed genes in this study, the data derived from the microarray analysis was subjected to a pre-screen of $95 \%$ confidence and a false discovery rate of 0.1 according to the methods of Benjamini (Reiner et al., 2003).

\subsection{Statistical Analysis}

Measurements unrelated to the microarray or qRTPCR analysis were analyzed using the MIXED procedure of SAS (2004) using a previously described model (Steele et al., 2012):

$$
\mathrm{Y}_{\mathrm{ij}}=\mu+\mathrm{D}_{\mathrm{i}}+\mathrm{T}_{\mathrm{j}}+(\mathrm{D} \times \mathrm{T})_{\mathrm{ij}}+\varepsilon_{\mathrm{ij}},
$$

where, $Y_{i j}$ is the dependent variable, $\mu$ is the variable mean, $D_{i}$ denotes the fixed effect of diet $(i=1,2), T_{j}$ is the fixed effect of time or day $(\mathrm{j}=1, . ., 7),(\mathrm{D} \times \mathrm{T})_{\mathrm{ij}}$ is the diet by time interaction $(\mathrm{ij}=1, \ldots, 14)$ and $\varepsilon_{\mathrm{ij}}$ represents the random residual error. Both diet and time were analyzed as fixed effects and day was analyzed as a repeated measurement with cow as the subject. The subject cow was treated to covariance structure measurements; the covariance structure resulting in the smallest Bayesian information criterion was used in this analysis.

\section{RESULTS}

\subsection{Physiological Parameters}

Table 1 represents the analysis of the diet which was formulated for this study. Both the Control and Butyrate groups received the same diet with the exception of supplemental butyrate in the treatment group.

Total rumen SCFA were analyzed for all animals and the data is presented in Table 3. Total SCFA levels differed significantly only on day 1 of the study and were higher in the Butyrate group (92.76 Vs $78.87 \mathrm{mM} \pm 4.51$; $\mathrm{p}=0.04$ ). However, as expected, total volatile butyrate levels were dramatically higher in the Butyrate group both on day 1 $(22.60 \mathrm{Vs} 9.88 \mathrm{mM} \pm 0.94, \mathrm{p} \leq 0.0001)$ and day $7(21.60 \mathrm{Vs}$ $8.60 \mathrm{mM} \pm 0.94, \mathrm{p} \leq 0.0001)$.

Total plasma LBP and free rumen LPS levels are also presented in Table 3. Plasma LBP levels were significantly higher in the Butyrate vs. the Control group on day 7 of the study (7.93 Vs $6.91 \mu \mathrm{g} \mathrm{mL}^{-1} \pm 0.29 ; \mathrm{P}=$ 0.024). Free LPS did not differ significantly for either treatment day between groups.

Also as expected, plasma BHBA levels were increased significantly due to treatment (Table 3). On day 1, Control Vs Butyrate levels were 909.50 vs. $4201.13 \mu \mathrm{M} \pm 265.24 \quad(\mathrm{p} \leq 0.001)$ and on day 7 of the study, levels of BHBA rose significantly from 799.50 to $3261.63 \mu \mathrm{M} \pm 265.24(\mathrm{p} \leq 0.001)$. Data for the serum acute phase protein SAA is presented in Table 3. No treatment differences were seen $(\mathrm{p}>0.05)$. 
Table 3. Rumen SCFA, plasma BHBA, plasma LBP, rumen LPS, and SAA concentrations with (Butyrate group) or without (Control group) $2.5 \%$ butyrate, DMI. Values are expressed as means \pm SEM; $n=8$ per Control or Butyrate group. P values represent comparison between treatments on individual days

\begin{tabular}{|c|c|c|c|c|c|c|c|}
\hline & \multicolumn{2}{|l|}{ Day 1} & \multicolumn{2}{|l|}{ Day 7} & \multirow[b]{2}{*}{ SEM } & \multicolumn{2}{|l|}{$\mathrm{P}$ value } \\
\hline & Control & Butyrate & Control & Butyrate & & Day 1 & Day 7 \\
\hline Total SCFA (mM) & 78.87 & 92.76 & 81.82 & 87.59 & 4.51 & 0.0400 & 0.3700 \\
\hline Acetate & 38.20 & 40.40 & 39.20 & 36.40 & 1.90 & 0.4100 & 0.3100 \\
\hline Propionate & 25.80 & 23.90 & 27.70 & 24.40 & 2.70 & 0.6200 & 0.4000 \\
\hline Isobutyrate & 1.70 & 2.20 & 2.50 & 1.90 & 0.29 & 0.2300 & 0.1800 \\
\hline Butyrate & 9.88 & 22.60 & 8.60 & 21.60 & 0.94 & $\leq 0.0001$ & $\leq 0.0001$ \\
\hline Isovalerate & 1.02 & 1.21 & 1.12 & 1.06 & 0.08 & 0.1100 & 0.6200 \\
\hline Valerate & 2.27 & 2.51 & 2.67 & 2.27 & 0.24 & 0.5000 & 0.2600 \\
\hline $\operatorname{BHBA}(\mu \mathrm{M})$ & 909.50 & 4201.13 & 799.50 & 3261.63 & 265.24 & $\leq 0.0010$ & $\leq 0.0010$ \\
\hline $\mathrm{LBP}(\mu \mathrm{g} / \mathrm{mL})$ & 6.68 & 6.80 & 6.91 & 7.93 & 0.29 & 0.7660 & 0.0240 \\
\hline LPS (EU/mL) & 52723.00 & 28892.00 & 14425.00 & 7517.25 & 8485.84 & 0.0570 & 0.5700 \\
\hline SAA (ng/mL) & 305.12 & 322.28 & 358.41 & 384.55 & 27.87 & 0.6700 & 0.5100 \\
\hline
\end{tabular}

Table 4. Effect of butyrate on rumen $\mathrm{pH}$ in Holstein cows with (Butyrate group) or without (Control group) butyrate supplementation at $2.5 \%$ DMI. Time in $\min /$ day; $\mathrm{AUC}=$ area under the curve in $\mathrm{pH} \leq 5.6 \times$ $\min /$ day

\begin{tabular}{llll}
\hline Treatment & Butyrate & Control & $\mathrm{P}$ \\
\hline Min & $5.20 \pm 0.05$ & $4.96 \pm 0.09$ & 0.04 \\
Mean & $5.67 \pm 0.04$ & $5.66 \pm 0.06$ & 0.89 \\
Max & $6.36 \pm 0.11$ & $6.55 \pm 0.16$ & 0.27 \\
Time $\mathrm{pH} \leq 5.6$ & $536 \pm 89$ & $598 \pm 97$ & 0.65 \\
AUC & $87 \pm 26$ & $168 \pm 40$ & 0.11 \\
\hline
\end{tabular}

Table 5. Dry matter intake, daily milk production, and daily milk production ratio. *The milk production ratio is adjusted for variations in dry matter intake related to treatment effects and indicates that the butyrate group was more efficient in the production of milk than was the control group

\begin{tabular}{lcccc}
\hline & Control & Butyrate & SEM & P-value \\
\hline $\begin{array}{l}\text { Dry Matter Intake, } \\
\text { DMI (kg/day) }\end{array}$ & 24.40 & 17.41 & 0.77 & $\leq 0.0001$ \\
$\begin{array}{l}\text { Daily Milk, DMP } \\
\text { Production (kg/day) }\end{array}$ & 41.93 & 34.74 & 2.50 & 0.0617 \\
$\begin{array}{l}\text { Daily Milk Production } \\
\text { Ratio, MPR (DMP/DMI)* }\end{array}$ & 1.67 & 1.96 & 0.09 & 0.0354 \\
\hline
\end{tabular}

As indicated previously, the effect of butyrate supplementation was examined on $\mathrm{pH}$ parameters in the rumen (Table 4). The minimum rumen $\mathrm{pH}$ reached during the time course of this study was lower in the
Control group than the Butyrate group $(4.96 \pm 0.09 \mathrm{Vs}$ $5.20 \pm 0.05 ; p=0.04)$. However, the addition of exogenous butyrate had no effect on the mean $\mathrm{pH}$, max $\mathrm{pH}$, the duration at which $\mathrm{pH}$ was below 5.6, or the area under the $\mathrm{pH}$ curve $(\mathrm{p}>0.05)$. DMI, milk production and production efficiency are presented in Table 5. Addition of exogenous dietary butyrate significantly lowered the DMI of the animals (17.41 Vs $24.40 \mathrm{~kg} \mathrm{day}^{-1} \pm 0.77$; $\mathrm{p} \leq 0.0001)$. Daily milk production was unaffected by treatment: $41.93 \mathrm{~kg} \mathrm{day}^{-1} \pm 2.50$ in the Control group to $34.74 \mathrm{~kg} \mathrm{day}^{-1} \pm 2.50$ in the Butyrate group $(\mathrm{p}>0.05)$. Interestingly, the daily milk production ratio, defined as the daily milk production Vs DMI, was significantly higher in the Butyrate group than in the Control group (1.96 Vs $1.67 \pm 0.09 ; \mathrm{p}=0.035)$.

\subsection{Microarray Screen, qRT-PCR and Pathway Analysis}

Gene expression results along with fold changes are presented in Table 6. Microarray data indicated the significant differential expression of 1191 genes (data not shown). These genes were screened in turn for involvement in NSHD, RM and IR pathways. Of the 49 genes selected for further analysis, 29 were confirmed significantly differentially expressed by qRT-PCR. Nine genes were found to be upregulated, 20 were downregulated and 20 were unaffected by butyrate supplementation. In turn, these genes were analyzed and placed into context-specific NSHD, RM and IR pathways, Fig. 1 and Table 7. 
Louis Dionissopoulos et al. / American Journal of Animal and Veterinary Sciences 8 (1): 8-27, 2013

Table 6. Relative gene expression in rumen papillae from cows treated with or without butyrate

\begin{tabular}{|c|c|c|c|}
\hline Symbol & Entrez Gene Name & Fold change & $P$-value \\
\hline LCN2 & lipocalin 2 & 27.0 & 0.000 \\
\hline MMP1 & matrix metallopeptidase 1 & 21.6 & 0.002 \\
\hline MUC16 & mucin 16 , cell surface associated & 14.9 & 0.001 \\
\hline GPX2 & glutathione peroxidase 2 (gastrointestinal) & 10.4 & 0.000 \\
\hline CSTA & cystatin A (stefin A) & 7.1 & 0.000 \\
\hline FUT1 & fucosyltransferase 1 & 4.3 & 0.000 \\
\hline SERPINE2 & serpin peptidase inhibitor, clade E member 2 & 3.7 & 0.000 \\
\hline BCAM & basal cell adhesion molecule & 1.5 & 0.006 \\
\hline RAC3 & ras-related $\mathrm{C} 3$ botulinum toxin substrate 3 & 1.4 & 0.044 \\
\hline MTOR & mechanistic target of rapamycin & -1.4 & 0.027 \\
\hline AKIRIN2 & akirin 2 & -1.7 & 0.000 \\
\hline NFKBIZ & nuclear factor of kappa light polypeptide gene enhancer inhibitor zeta & -1.7 & 0.001 \\
\hline ACVR2A & activin A receptor, type IIA & -1.7 & 0.001 \\
\hline LAMB1 & laminin, beta 1 & -1.7 & 0.020 \\
\hline FRS2 & fibroblast growth factor receptor substrate 2 & -1.8 & 0.001 \\
\hline PPARD & peroxisome proliferator-activated receptor delta & -1.8 & 0.000 \\
\hline NFKB2 & nuclear factor of kappa $b$ light polypeptide gene enhancer 2 & -2.0 & 0.001 \\
\hline LBP & lipopolysaccharide binding protein & -2.0 & 0.006 \\
\hline NEDD4L & E3 ubiquitin protein ligase & -2.1 & 0.000 \\
\hline SGK1 & serum/glucocorticoid regulated kinase 1 & -2.3 & 0.001 \\
\hline DEDD2 & death effector domain containing 2 & -2.6 & 0.000 \\
\hline MAP3K8 & mitogen-activated protein kinase kinase kinase 8 & -2.6 & 0.001 \\
\hline PARD6B & par- 6 partitioning defective 6 homolog beta & -2.6 & 0.000 \\
\hline PLIN2 & perilipin 2 & -2.9 & 0.000 \\
\hline $\mathrm{ADA}$ & adenosine deaminase & -3.3 & 0.000 \\
\hline HPGD & hydroxyprostaglandin dehydrogenase 15-(NAD) & -3.3 & 0.000 \\
\hline FMO5 & flavin containing monooxygenase 5 & -3.4 & 0.000 \\
\hline BMP6 & bone morphogenetic protein 6 & -3.7 & 0.000 \\
\hline TCHH & Trichohyalin & -5.0 & 0.000 \\
\hline CD14/TLR4/LY96 & TLR4 Receptor Complex & unchanged & ns \\
\hline EGF & epidermal growth factor & unchanged & ns \\
\hline EGFR & epidermal growth factor receptor & unchanged & ns \\
\hline ERK $1 / 2$ & extracellular signal related kinase $1 / 2$ & unchanged & ns \\
\hline Fgf & fibroblast growth factor & unchanged & ns \\
\hline Fgfr & fibroblast growth factor receptor & unchanged & ns \\
\hline FN1 & fibronectin 1 & unchanged & ns \\
\hline IGFBP7 & IGF binding protein 7 & unchanged & ns \\
\hline IL10 & interleukin 10 & unchanged & ns \\
\hline LY96 & lymphocyte antigen 96 & unchanged & ns \\
\hline MIF & macrophage migration inhibitory factor & unchanged & ns \\
\hline MLST8 & MTOR associated protein & unchanged & ns \\
\hline NFKB1 & nuclear factor of kappa light polypeptide gene enhancer 1 & unchanged & ns \\
\hline PTGS1 & prostaglandin-endoperoxide synthase 1 & unchanged & ns \\
\hline PTGS2 & prostaglandin-endoperoxide synthase 2 & unchanged & ns \\
\hline SMAD1 & mothers against decapentaplegic homolog 1 & unchanged & ns \\
\hline STAT6 & signal transducer and activator of transcription 6 , interleukin-4 induced & unchanged & ns \\
\hline TGFB1I1 & transforming growth factor beta-1-induced transcript 1 & unchanged & ns \\
\hline TLR4 & toll-like receptor 4 & unchanged & ns \\
\hline TNFRSF6B & Tumor necrosis factor receptor superfamily member $6 \mathrm{~B}$ & unchanged & $\mathrm{ns}$ \\
\hline
\end{tabular}


Table 7. Gene expression results and interpretation. *Biological interpretation in lieu of experimental model. Abbreviations: NSHD, non-specific host defense; Remodel, remodeling of cellular architecture; Other, non-categorized; IR, immune response;

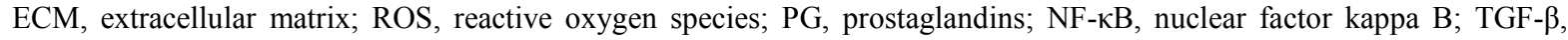
transforming growth factor type beta; TLR4, toll-like receptor 4

\begin{tabular}{|c|c|c|c|c|c|}
\hline Category & Symbol & Function & $\begin{array}{l}\text { Fold } \\
\text { Change }\end{array}$ & $\begin{array}{l}\text { Contextual } \\
\text { Meaning* }\end{array}$ & Ref. \\
\hline NSHD & LCN2 & $\begin{array}{l}\text { Iron sequestration } \\
\text { from bacteria }\end{array}$ & 27 & $\begin{array}{l}\downarrow \text { bacterial } \\
\text { growth }\end{array}$ & $\begin{array}{l}\text { (Flo et al., 2004; } \\
\text { Schmidt-Ott et al., 2007) }\end{array}$ \\
\hline $\mathrm{RM}$ & MMP1 & $\begin{array}{l}\text { ECM remodeling; } \\
\text { degradation of ECM }\end{array}$ & 21.6 & Adaptation & (Pendas et al., 1996) \\
\hline NSHD & MUC16 & $\begin{array}{l}\text { Mucous production and } \\
\text { protection of epithelium }\end{array}$ & 14.9 & $\downarrow$ bacterial attachment & (Perez and Gipson, 2008) \\
\hline NSHD & GPX2 & $\begin{array}{l}\text { Protection against bacterial } \\
\text { production of ROS in rumen }\end{array}$ & 10.4 & $\downarrow$ bacterial attachment & $\begin{array}{l}\text { (Brigelius-Flohe } \\
\text { and Kipp, 2012) }\end{array}$ \\
\hline NSHD & CSTA & Promotes cell-cell adhesion & 7.1 & $\downarrow$ bacterial pathogenicity & (Blaydon et al., 2011) \\
\hline NSHD & FUT1 & $\begin{array}{l}\text { Regulates pathogen } \\
\text { attachment to epithelium }\end{array}$ & 4.3 & $\downarrow$ bacterial attachment & $\begin{array}{l}\text { (Yan et al., 2003; } \\
\text { Wang et al., 2012) }\end{array}$ \\
\hline NSHD & SERPINE2 & $\begin{array}{l}\text { Serine protease providing } \\
\text { resistance to bacterial colonization }\end{array}$ & 3.7 & $\downarrow$ bacterial attachment & (Luo et al., 2011) \\
\hline RM & BCAM & ECM receptor & 1.5 & Adaptation & (Eyler and Telen, 2006) \\
\hline $\mathrm{RM}$ & RAC3 & $\begin{array}{l}\text { Cell growth, reorganization } \\
\text { of the cytoskeleton }\end{array}$ & 1.4 & Adaptation & (Haataja et al., 2002) \\
\hline $\mathrm{RM}$ & MTOR & $\begin{array}{l}\text { Various; reorganization } \\
\text { of the cytoskeleton }\end{array}$ & -1.4 & Adaptation & (Sarbassov et al., 2004) \\
\hline IR & AKIRIN2 & $\begin{array}{l}\text { Downstream TLR4 } \\
\text { effector; regulates NF-kB }\end{array}$ & -1.7 & Adaptation $\downarrow$ IR & (Goto et al., 2008) \\
\hline IR & NFKBIZ & $\mathrm{NF}-\kappa \mathrm{B}$ regulator & -1.7 & Adaptation $\downarrow$ IR & $\begin{array}{l}\text { (Cowland et al., 2006; } \\
\text { Totzke et al., 2006) }\end{array}$ \\
\hline $\mathrm{RM}$ & ACVR2A & $\begin{array}{l}\text { Reorganization of the cytoskeleton; } \\
\text { downregulates immune response }\end{array}$ & -1.7 & Adaptation $\downarrow$ IR & $\begin{array}{l}\text { (Lebrun et al., 1999; } \\
\text { Tsuchida et al., 2004) }\end{array}$ \\
\hline RM & LAMB1 & $\begin{array}{l}\text { ECM protein necessary for } \\
\text { signaling and structural integrity }\end{array}$ & -1.7 & Adatpation & (Taniguchi et al., 2009) \\
\hline $\mathrm{RM}$ & FRS2 & $\begin{array}{l}\text { ECM reorganization; } \\
\text { FGF receptor sigalling }\end{array}$ & -1.8 & Adaptation & (Ong et al., 2000) \\
\hline $\mathrm{RM}$ & PPARD & ECM reorganization & -1.8 & Adaptation & (Tan et al., 2007) \\
\hline IR & NFKB2 & $N F-\kappa B$ regulator & -2.0 & Adaptation $\downarrow$ IR & (Al-Sadi et al., 2010) \\
\hline IR & LBP & Mediator of LPS activity & -2.0 & Adaptation $\downarrow$ IR & (Gray et al., 1993) \\
\hline IR & NEDD4L & $\begin{array}{l}\text { Negative regulator of } \\
\text { TGF- } \beta \text { signaling }\end{array}$ & -2.1 & Adaptation $\downarrow$ IR & (Kuratomi et al., 2005) \\
\hline Other & SGK1 & $\mathrm{Na}^{+}$channel regulatior & -2.3 & Unknown & (Grahammer et al., 2006) \\
\hline RM & DEDD2 & $\begin{array}{l}\text { ECM/cellular remodeling; } \\
\text { low levels decrease apoptosis }\end{array}$ & -2.6 & Adaptation & (Lee et al., 2002) \\
\hline IR & MAP3K8 & $\begin{array}{l}\text { Various; low levels } \\
\text { decrease immune response }\end{array}$ & -2.6 & Adaptation $\downarrow$ IR & $\begin{array}{l}\text { (Miyoshi et al., 1991; } \\
\text { Hatziapostolou et al., 2011) }\end{array}$ \\
\hline NSHD & PARD6B & $\begin{array}{l}\text { Cell polarization; low levels } \\
\text { may increase tight junction integrity }\end{array}$ & -2.6 & Adaptation & (Yamanaka et al., 2003) \\
\hline IR & PLIN2 & $\begin{array}{l}\text { Maintenance of adipose tissue; } \\
\text { may decrease macrophage recruitment }\end{array}$ & -2.9 & Unknown $\downarrow$ IR & (Hao et al., 2011) \\
\hline NSHD & $\mathrm{ADA}$ & Maintenance of the immune system & -3.3 & Adaptation $\downarrow$ IR & (Wilson et al., 1991) \\
\hline NSHD & HPGD & $\begin{array}{l}\text { Metabolism of PG; low levels } \\
\text { maintain protective PG }\end{array}$ & -3.3 & Adaptation & (Cho et al., 2006) \\
\hline Other & FMO5 & $\begin{array}{l}\text { Metabolism of drugs, } \\
\text { pesticides, xenobiotics }\end{array}$ & -3.4 & Unknown & (Janmohamed et al., 2001) \\
\hline $\mathrm{RM}$ & BMP6 & $\begin{array}{l}\text { Matrix growth factor; low } \\
\text { levels may aid reepithelialization }\end{array}$ & -3.7 & Adaptation & (Kaiser et al., 1998) \\
\hline NSHD & $\mathrm{TCHH}$ & $\begin{array}{l}\text { Keratin filament-associated protein; } \\
\text { low levels prevent rigidity of ECM }\end{array}$ & -5.0 & Adaptation & (Steinert et al., 2003) \\
\hline
\end{tabular}




\section{DISCUSSION}

It has been shown that adaptation to energy-dense, high carbohydrate diets in dairy cows is facilitated by structural changes in the rumen favouring extracellular matrix remodelling (Steele et al., 2011a). This effect does not always follow a profound inflammatory phase and it was determined that favourable adaptive changes in the rumen take place beginning 1 week after a high grain challenge. The aim of the current study was to determine the efficacy of butyrate supplementation in ameliorating the negative ruminal effects induced by feeding a high carbohydrate to lactating dairy cows. In addition, since the effects of SARA on rumen physiological dynamics have been reported (Keunen et al., 2002; Penner et al., 2007), we sought to determine the effects of butyrate treatment on milk production, milk components, $\mathrm{pH}$, SCFA, SCFA metabolism, the effects on NSHD and evidence for an IR.

\subsection{Physiological Parameters}

We previously reported $\mathrm{pH}$ results in cows fed a high grain diet that is in agreement with the current study (Steele et al., 2012). Of note however, is the effect of supplemental butyrate on minimum $\mathrm{pH}$ reported; the rumen of cows in the Control group reached a lower $\mathrm{pH}$ than did the Butyrate group. Since butyrate itself is a weak acid, it is unlikely that buffering by its conjugate base would be responsible for this effect. However, it is possible that butyrate altered the metabolic flux of the rumen, favouring the neutralization of $\mathrm{H}^{+}$through the efflux of bicarbonate. Similar effects have been reported (Kristensen et al., 1998; Penner et al., 2009a; Aschenbach et al., 2010).

A high dietary carbohydrate load such as that seen in this study is expected to favour ketogenesis. In the rumen, SCFA are created as the result of fermentation by resident microbes and are metabolized within the site of absorption in the epithelia of the rumen, prior to making their appearance as substrates in the general tissue beds (Bergman, 1990; Kristensen et al., 1998). The ensuing hyperketonemia and ketosis can be confirmed through plasma analysis of BHBA levels (Penner et al., 2009b). Indeed, plasma BHBA levels were raised considerably in the Butyrate group as expected, which confirmed experimental ketosis. This had a direct effect on DMI, which was substantially lower in the Butyrate group; the effects of high SCFA levels on increasing satiety and decreasing appetite have been documented previously (Arora et al., 2011; Lin et al., 2012). And although supplemental butyrate had no effect on daily milk production, milk fat, or milk protein, the efficiency of milk production was higher in the Butyrate cows. These results appear to be a function of a decreased DMI. The fact that the milk parameters differed in grain content from previous studies is likely due to the lower energy density of the current SARA diet (Lykos et al., 1997; Keunen et al., 2002).

In such a carbohydrate-rich diet, both commensal and pathogenic microbes thrive. This is because such microbes can use the more readily available sugars as a preferential metabolic substrate (Motoi et al., 1993; Gozho et al., 2005; Thibault et al., 2010). Although the grain level in our study was not as high as that previously reported, the $45 \% \mathrm{NFC}$ is sufficient to promote the growth of gram negative bacteria, which is correlated with the levels of rumen LPS (Zebeli and Ametaj, 2009). Although the LPS levels in this study are in relative agreement with those published earlier (Khafipour et al., 2009a; 2009b; Li et al., 2012), it is not clear whether they are in sufficient concentration to favour transmigration and to trigger an immune response. In order for such a response to exist, free LPS must be transported to effector cells of the immune system by the soluble acute phase protein, LBP (Muta and Takeshige, 2001). Here we report that butyrate supplementation increases plasma levels of LBP. However, this effect may be muted by the addition of butyrate, as several groups have reported reductions in the downstream effects of LPS-mediated induction of the immune system (Chakravortty et al., 2000; Huuskonen et al., 2004; Morikawa et al., 2004; Ni et al., 2010) under similar conditions. In addition, SAA, also an acute phase protein, was unaffected by the addition of butyrate. Together, the data for LPS, LBP and SAA contradict earlier findings using similar models (Dionissopoulos et al., $2012 \mathrm{a} ; 2012 \mathrm{~b}$ ), that although SARA can have profound effects on the physiology of the rumen, the bacterial overgrowth that typically occurs is not sufficient enough to result in a systemic inflammatory response. The tissue signals generated as a result of SARA at the site of tissue damage (Steele et al., 2011a) likely act locally in an autocrine or paracrine manner.

\subsection{Gene Expression and Pathway Analysis}

The rumen epithelium is part of a remarkable system that is meant to facilitate nutrient absorption and to function as a barrier to disease-causing organisms (Henrikson and Stacy, 1971). The molecular mechanisms responsible for the effects of rumen recovery or adaptation following SARA-mediated epithelial damage have not been determined. In 
addition, since butyrate has been shown to be beneficial in models of gastrointestinal disease in a variety of species (Segain et al., 2000; Huuskonen et al., 2004; Borthakur et al., 2008; Hamer et al., 2008; Thibault et al., 2010), we sought to also determine the efficacy of exogenous butyrate administration by studying changes in rumen epithelial gene expression. To this end, a microarray analysis, followed by qRT-PCR confirmation was completed based on information from existing databases to determine the importance of any affected metabolic pathways at the molecular level. In this study it was found that the observed changes in gene expression could be grouped into three categories: 1. NSHD genes (LCN2, MMP1, MUC16, GPX2, CSTA, FUT1, SERPINE2, PARD6B, ADA, HPGD and TCHH), 2. RM Genes (BCAM, RAC3, MTOR, ACVR2A, LAMB1, FRS2, PPARD, DEDD2 and BMP6) and 3. Genes involved in the IR (NFKBIZ, NFKB2, LBP, NEDD4L, MAP3K8 and PLIN2). The individual genes, gene expression, role and contextual meaning are presented in Table 7.

NSHD genes are involved in conferring general protection to the organism and can take the form of increased barrier integrity, mucin production and reduced pathogen viability or attachment (Canonica, 2005). For example, by acting to sequester soluble $\mathrm{Fe}^{3+}$ from microbial siderophores, increased LCN2 expression can reduce the rate of microbial growth (Flo et al., 2004; Schmidt-Ott et al., 2007). Increased CSTA and GPX2 expression promote the maintenance and integrity of epithelial tight junctions (Blaydon et al., 2011) and limit the damaging effects of reactive oxygen species secreted by microorganisms (Brigelius-Flohe and Kipp, 2012). As such, they prevent the infiltration of potentially pathogenic bacteria into the deeper epithelial layers. Mucous layers are known lubricating barriers in epithelial cells and are a necessary component in the prevention of pathogen attachment (Perez and Gipson, 2008). FUT1 is an epithelial cell-surface receptor for pathogenic strains of $\mathrm{E}$. coli and changes in its expression are thought to modulate pathogen attachment to epithelial cells (Yan et al., 2003; Wang et al., 2012) as is the expression of SERPINE2 (Luo et al., 2011). MUC16 which was highly elevated in this study is a glycosylated matrix protein known to provide a protective role in epithelial tissues (Perez and Gipson, 2008). PARD6B is one of a group of genes responsible for attachment and polarity of epithelial cells to basolateral membranes (Suzuki et al., 2001). In this study, PARD6B was downregulated which is in agreement with Gao et al. (2002) who found an inverse correlation between PARD6B expression and tight junction integrity. ADA is a ubiquitous enzyme which is needed for the development and maintenance of the immune system (Wilson et al., 1991). In studies where ADA expression was repressed or suppressed entirely, the immune response was limited and under full suppression, forms the biological basis for Severe Combined Immunodeficiency (SCID) mice (Martin Jr. and Gelfand, 1981; Wilson et al., 1991). ADA was reduced in our study helping to reduce the extent and severity of the immune response. HPGD, an enzyme responsible for prostaglandin metabolism, was reduced in our study. Prostaglandins can have diverse roles depending on the presence of disease. For example, Cyclooxygenase-1 (COX1) is constitutively expressed in a normal gastrointestinal tract and is responsible for the expression of protective prostaglandins, namely PGE2. COX2 is inducible and its expression rapidly increases in response to pathogenic stimuli (Cho et al., 2006; Wallace, 2008). It follows then that the lower expression of HPGD seen in this study can lead to protective effects in the rumen by controlling inflammation and helping to maintain levels of COX1 metabolites.

Genes involved in remodelling or adaptation is those that are responsible for the degradation of the extracellular matrix, its reorganization, cellular movement, signalling and adaptation to new metabolic requirements. The particulars of ECM reorganization with respect to wound healing have been reviewed extensively (Schreml et al., 2010). Briefly, ECM reorganization follows a tightly choreographed series of events initiated by the degradation of existing ECM proteins, followed by clearance, the deposition of a new matrix milieu and proliferation and differentiation of epithelial cells favouring the new conditions. MMP1 $(+21.6)$ is a matrix metallopeptidase secreted by subepithelial fibroblasts in response to the need for a rearrangement of extracellular architecture in response to injury, growth, or adaptation (Birkedal-Hansen et al., 1993; Pendas et al., 1996; 1997). These events involve a wide variety of genes. In this study, BCAM (a receptor for matrix proteins) was elevated in addition to RAC3, which together aid in the remodelling process (Haataja et al., 2002; Eyler and Telen, 2006). It is unknown how long the early phases of remodeling occur in rumen epithelium. However, evidence from this study suggests that on the day the biopsies were taken for analysis, the animals were still in the early phase of remodeling. This can be seen in the downregulation of LAMB1 (Taniguchi et al., 2009), BMP6 (Kaiser et al., 1998), ACVR2A (Lebrun et al., 1999; Tsuchida et al., 2004), PPARD (Tan et al., 2007), TCHH (Steinert et al., 2003) and in the downregulation of MTOR, which has been shown to be necessary for ECM degradation (Sarbassov et al., 2004; Ong et al., 2007). 
Louis Dionissopoulos et al. / American Journal of Animal and Veterinary Sciences 8 (1): 8-27, 2013

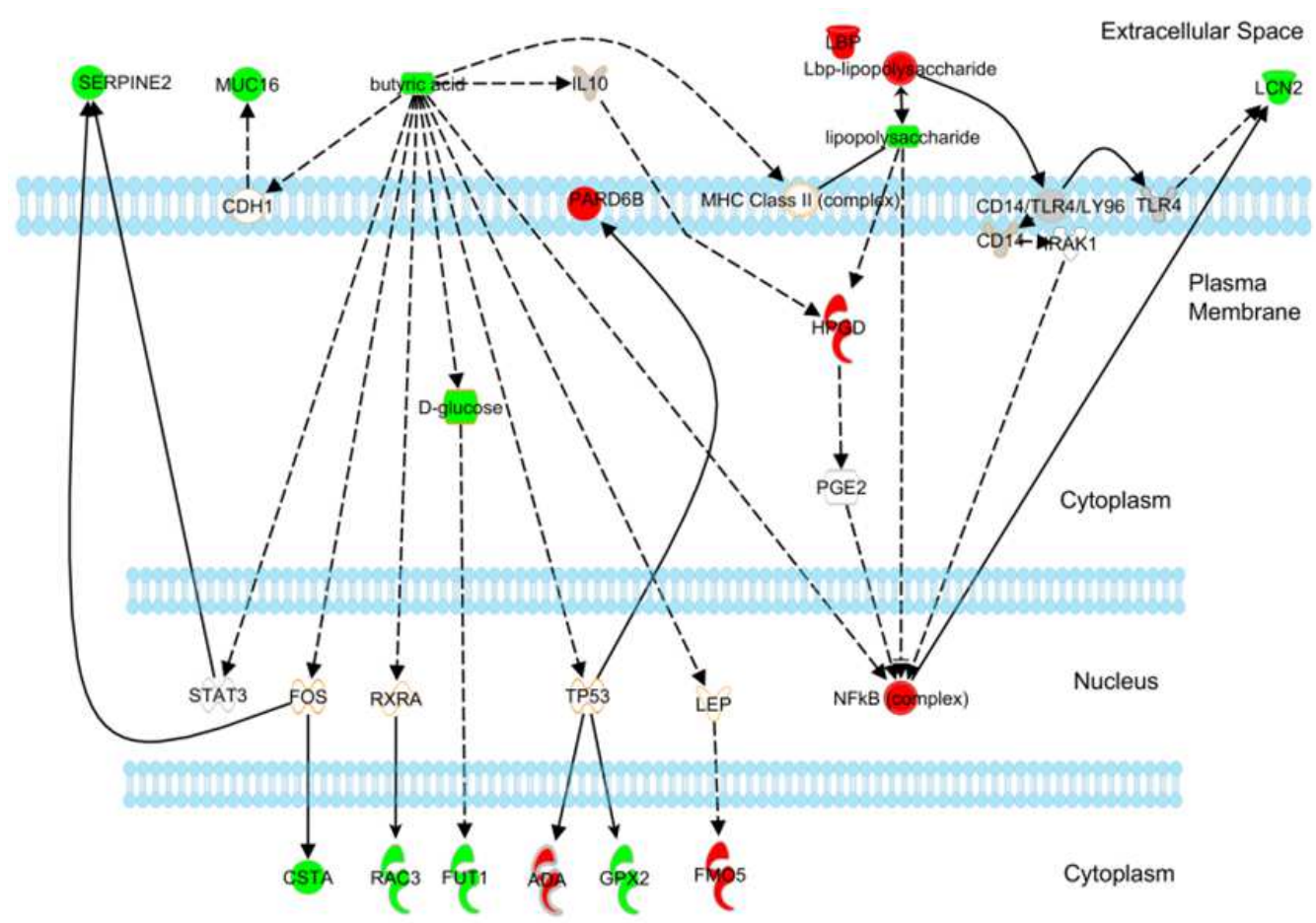

(A)

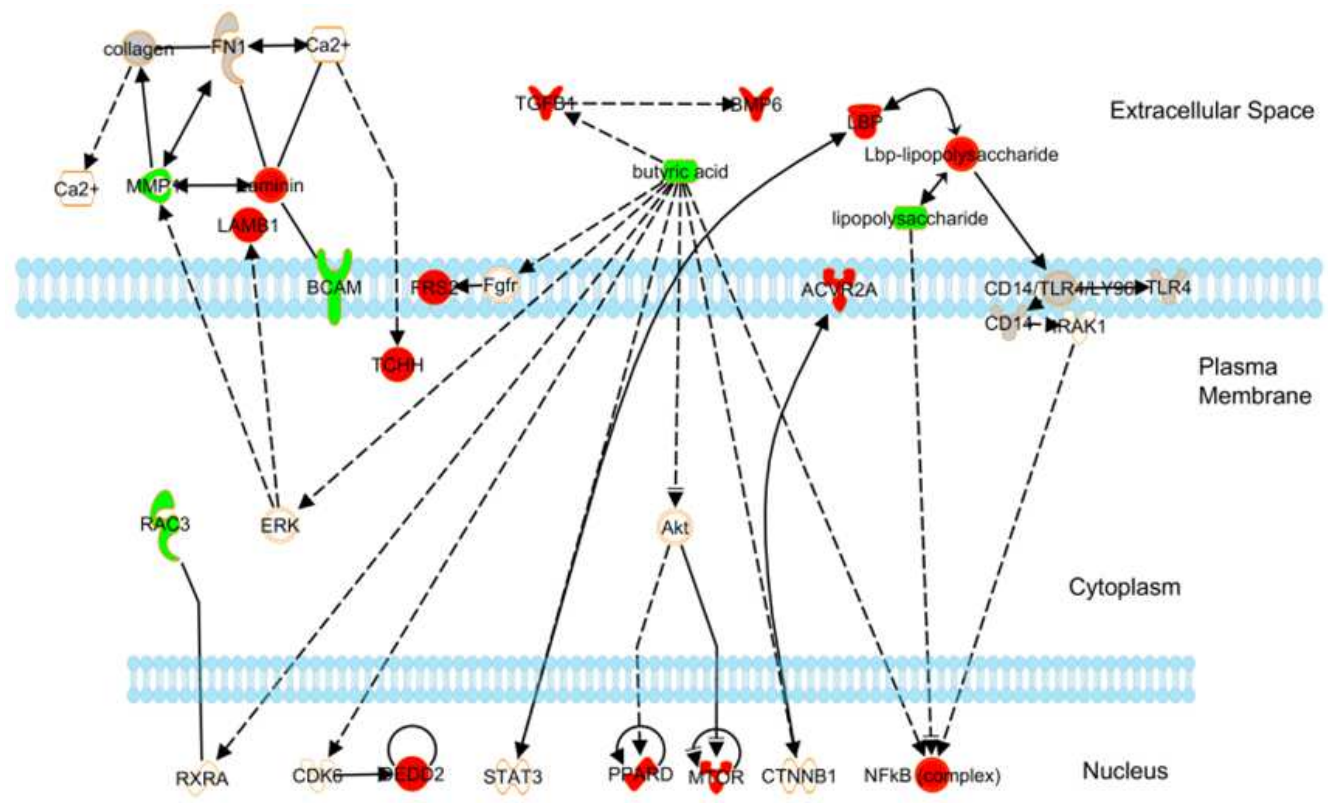

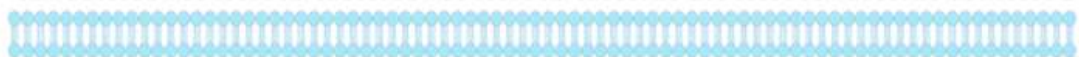

(B)

Cytoplasm 

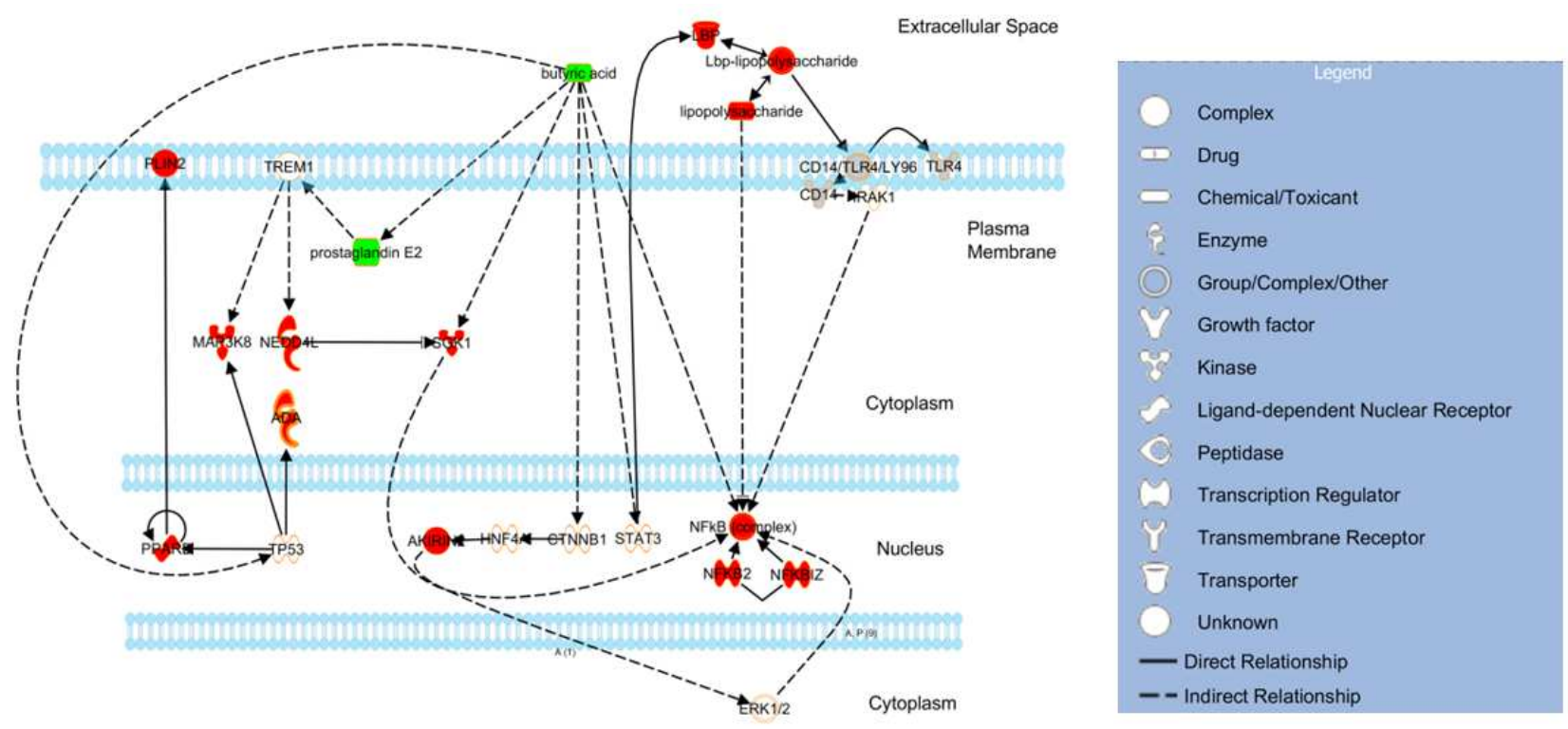

(C)

Fig. 1. Context-specific pathway analysis of genes upregulated (green) or downregulated (red) due to the addition of exogenous butyrate supplementation at 2.5\% DMI. Panels A, B, and C represent genes involved in Non-Specific Host Defense (NSHD), remodeling, or the Immune Response (IR) respectively. Genes coloured gray indicate no change while those in white are present as proposed pathway intermediates where necessary, but were not represented in the analysis

In a similar fashion, FRS2, which plays an integral role in cellular adhesion and growth (Ong et al., 2000; Norambuena and Schwartz, 2011), was downregulated and thus likely contributed to the degradation and reorganization of the ECM. Finally, during the adaptive process, recovering healthy epithelium is induced to proliferate. An anti-proliferative factor, DEDD2 was downregulated in this study. Apoptosis is usually seen in polymorphonuclear cells following the inflammatory phase of wound healing in skin models (Lee et al., 2002; Eming et al., 2007).

IR genes are general indicators of immune system status and stimulation. Indeed, a continued and prolonged immune response such as that seen in SARA, can be detrimental to the growth and maintenance of an organism. In fact, the partitioning of nutrients for the execution of an immune response is well known (Dionissopoulos et al., 2001; Meazza et al., 2004; Li et al., 2006). One of the most important ways in which tissues regulate the immune response is through the activation or suppression of $\mathrm{NF}-\kappa \mathrm{B}$ signalling pathways (Gilmore, 2006). In this study, all genes in the IR category were downregulated by the addition of exogenous butyrate. Most of these are upstream effectors of NF- $\mathrm{B}$ (AKIRIN2, NFKBIZ, NFKB2) (Cowland et al., 2006; Totzke et al., 2006; Goto et al., 2008; Al-Sadi et al., 2010). Others such as LBP (- 2.0-fold), require binding of free LPS to its receptor, TLR4 for downstream signalling events to take place (Gray et al., 1993). In addition, Li et al. (2011) were able to determine that NEDD4L is a positive regulator of $\mathrm{NF}-\kappa \mathrm{B}$ which is in agreement with our results. Similarly, the ability of MAP3K8 and PLIN2 to activate the NF- $\mathrm{BB}$ pathway has been documented (Chan and Reed, 2005; Cismasiu et al., 2009; Mattos et al., 2010). These direct relationships are supported by results presented here.

All expression data was compiled and analyzed for pathway interactions using the Ingenuity Systems TM KEGG database (Tanabe and Kanehisa, 2012; Zhou, 2013). As in Table 7, the PCR data was placed in the three functional categories of NSHD, RM and IR and hypothetical pathway diagrams were constructed for each based on experimental findings of the response to LPS and exogenous butyrate following a grain challenge. These figures clearly demonstrate the central role of butyrate in our experimental model. Figure 1A indicates the beneficial effects of Butyrate on NHSD. Figure 1B represents the effect of butyrate on the modulation of the rumen Epithelial Extracellular Matrix (ECM) and Fig. 1C shows the downregulation of the immune response to LPS following butyrate administration. Butyrate has been well known as a Histone Deacetylase (HDAC) inhibitor and its effects in attenuating inflammatory 
conditions have been hypothesized to be the result of modulation of the NF- $\kappa \mathrm{B}$ signalling cascade at multiple levels (Miyoshi et al., 2011). TLR4/NF- $\mathrm{BB}$ controls the expression of many inflammatory genes (Fig. 1C) and so it makes sense that it can serve as a control point for limiting the IR (Suuronen et al., 2003). Indeed, several studies have reported a decrease in the TLR4/NF- $\mathrm{BB}$ response to LPS following butyrate administration (Huuskonen et al., 2004; Wu et al., 2012). In addition to reductions in NF- $\mathrm{BB}$ family genes, we propose that butyrate limits the extent of the immune response to LPS by reducing the expression of additional genes shown to be effectors of the IR. Although we have placed the effects of butyrate in three different categories, it was our intent to demonstrate that butyrate mediates its beneficial effects through the differential expression of multiple genes related to NSHD, remodelling and the IR within epithelial cells exposed to LPS.

To our knowledge, this type of analysis has not been conducted on rumen epithelium adapting to an acidotic diet in response to exogenous butyrate. As with any new therapeutic intervention, it is not known if its administration will have negative effects on the wellbeing on the host. This type of approach allows the quantification of such findings and demonstrates the viability of butyrate supplementation in the treatment of SARA in response to a high grain/high energy diet.

\section{CONCLUSION}

Although the data presented here indicated that butyrate supplementation had little effect on milk parameters and $\mathrm{pH}$, it can be seen that the extent of the immune response in SARA is further limited by reductions in the expression of the acute phase protein, LPS. In addition, gene expression data clearly shows the enhancement of preparative and compensatory mechanisms in SARA facilitated by butyrate. The advanced pathways explored here represent potential biomarkers and indicate the pervasive and yet benign nature of butyrate supplementation. It can be seen that exogenous butyrate reduces the expression of key inflammatory markers, enhances non-specific cellular defences to microorganisms and the remodelling of the ECM to favour adaptation to a high grain/high energy environment.

\section{ACKNOWLEDGEMENT}

The researchers would like to acknowledge continued financial support from Agriculture and Agri-Food Canada,
Ontario Ministry of Agriculture Food and Rural Affairs, Dairy Farmers of Canada and the National Sciences and Engineering Research Council of Canada. In addition, we would like to thank Katie Wood, Erin Hendrikson, Dr. Sun, Jing Zhang and the staff of the Ponsonby Research Station (University of Guelph) for their invaluable help during the conduct of this study and Ivan Girard of Probiotech International for providing the butyrate.

\section{REFERENCES}

Ahmad, M.S., S. Krishnan, B.S. Ramakrishna, M. Mathan and A.B. Pulimood et al., 2000. Butyrate and glucose metabolism by colonocytes in experimental colitis in mice. Gut., 46: 493-499. PMID: 10716678

Al-Sadi, R., D. Ye, H.M. Said and T.Y. Ma, 2010. IL1beta-induced increase in intestinal epithelial tight junction permeability is mediated by MEKK-1 activation of canonical NF-kappaB pathway. Am. J. Pathol., 177: 2310-2322. PMID: 21048223

AlZahal, O., B. Rustomo, N.E. Odongo, T.F. Duffield and B.W. McBride, 2007. Technical note: A system for continuous recording of ruminal $\mathrm{pH}$ in cattle. J. Animal Sci., 85: 213-217. PMID: 17179558

Aoyama, M., J. Kotani and M. Usami, 2010. Butyrate and propionate induced activated or non-activated neutrophil apoptosis via HDAC inhibitor activity but without activating GPR-41/GPR-43 pathways. Nutrition, 26: 653-661. DOI: 10.1016/j.nut.2009.07.006

Arora, T., R. Sharma, G. Frost, 2011. Propionate. Antiobesity and satiety enhancing factor? Appetite 56: 511-515. DOI: 10.1016/j.appet.2011.01.016

Aschenbach, J.R., N.B. Kristensen, S.S. Donkin, H.M. Hammon and G.B. Penner, 2010. Gluconeogenesis in dairy cows: The secret of making sweet milk from sour dough. IUBMB Life, 62: 869-877. DOI: 10.1002/iub.400

Bergman, E.N., 1990. Energy contributions of volatile fatty acids from the gastrointestinal tract in various species. Physiol. Rev., 70: 567-590. PMID: 2181501

Birkedal-Hansen, H., W.G. Moore, M.K. Bodden, L.J. Windsor and B. Birkedal-Hansen et al., 1993. Matrix metalloproteinases: a review. Crit. Rev. Oral. Biol. Med., 4: 197-250. PMID: 8435466

Blaydon, D.C., D. Nitoiu, K.M. Eckl, R.M. Cabral and P. Bland et al., 2011. Mutations in CSTA, encoding Cystatin A, underlie exfoliative ichthyosis and reveal a role for this protease inhibitor in cell-cell adhesion. Am. J. Hum. Genet., 89: 564-571. DOI: 10.1016/j.ajhg.2011.09.001 
Borthakur, A., S. Saksena, R.K. Gill, W.A. Alrefai and K. Ramaswamy et al., 2008. Regulation of monocarboxylate transporter 1 (MCT1) promoter by butyrate in human intestinal epithelial cells: Involvement of NF-kB pathway. J. Cell. Biochem., 103: 1452-1463. DOI: $10.1002 /$ jcb. 21532

Brigelius-Flohe, R. and A.P. Kipp, 2012. Physiological functions of GPx2 and its role in inflammationtriggered carcinogenesis. Ann. NY Acad. Sci., 1259: 19-25. DOI: $10.1111 / \mathrm{j} .1749-6632.2012 .06574 . \mathrm{x}$

Calder, P.C., 2008. Polyunsaturated fatty acids, inflammatory processes and inflammatory bowel diseases. Mol. Nutr. Food. Res., 52: 885-897. DOI: 10.1002/mnfr.200700289

Canonica, G.W., 2005. Expert review of clinical immunology: A breakthrough in the future. Expert Rev. Clin. Immunol., 1: 1-2. DOI: 10.1586/1744666X.1.1.1

Chakravortty, D., N. Koide, Y. Kato, T. Sugiyama and M.M. Mu et al., 2000. The inhibitory action of butyrate on lipopolysaccharide-induced nitric oxide production in RAW 264.7 murine macrophage cells. J. Endotoxin. Res., 6: 243-247. PMID: 11052179

Chan, H. and J.C. Reed, 2005. TRAF-dependent association of protein kinase Tp12/COT1 (MAP3K8) with CD40. Biochem. Biophys. Res. Commun., 328: 198-205. DOI: 10.1016/j.bbrc.2004.12.155

Cho, H., L. Huang, A. Hamza, D. Gao and C.G. Zhan et al., 2006. Role of glutamine 148 of human 15hydroxyprostaglandin dehydrogenase in catalytic oxidation of prostaglandin E2. Bioorg. Med. Chem., 14: 6486-6491. DOI: 10.1016/j.bmc.2006.06.030

Cismasiu, V.B., J. Duque, E. Paskaleva, D. Califano and S. Ghanta et al., 2009. BCL11B enhances $\mathrm{TCR} / \mathrm{CD} 28$-triggered NF- $\kappa \mathrm{B}$ activation through upregulation of Cot kinase gene expression in $\mathrm{T}$ lymphocytes. Biochem. J., 417: DOI: 10.1042/BJ20080925

Cowland, J.B., T. Muta and N. Borregaard, 2006. IL1beta-specific up-regulation of neutrophil gelatinase-associated lipocalin is controlled by IkappaB-zeta. J. Immunol., 176: 5559-5566. PMID: 16622025

Desreumaux, P., L. Dubuquoy, S. Nutten, M. Peuchmaur and W. Englaro et al., 2001. Attenuation of colon inflammation through activators of the retinoid $\mathrm{X}$ receptor (RXR)/peroxisome proliferator-activated receptor gamma (PPARgamma) heterodimer. A basis for new therapeutic strategies. J. Exp. Med., 193: 827-838. PMID: 11283155
Desreumaux, P., O. Ernst, K. Geboes, L. Gambiez and D. Berrebi et al., 1999. Inflammatory alterations in mesenteric adipose tissue in Crohn's disease. Gastroenterol., 117: 73-81. PMID: 10381912

Dionissopoulos, L., C.F.M. De Lange, C.E. Dewey, J.I. MacInnes and R.M. Friendship, 2001. Effect of health management strategy during rearing on grower-finisher pig performance and selected indicators of immune system stimulation. Can. J. Anim. Sci., 81: 179-187. DOI: 10.4141/A00-020

Dionissopoulos, L., C.E. Dewey, H. Namkung and C.F.M. De Lange, 2006. Interleukin-1ra increases growth performance and body protein accretion and decreases the cytokine response in a model of subclinical disease in growing pigs. Animal Sci., 82: 509-515. DOI: 10.1079/Asc200654

Dionissopoulos, L., M.A. Steele, O. AlZahal, B.W. McBride, 2012a. Adaptation to high grain diets proceeds through minimal immune system stimulation and differences in extracellular matrix protein expression in a model of subacute ruminal acidosis in non-lactating dairy cows. Am. J. Animal Vet. Sci. 7: 84-91. DOI: 10.3844/ajavsp.2012.84.91

Dionissopoulos, L., M.A. Steele, O. AlZahal, J.C. Plaizier and B.W. McBride, 2012b. A characterization of inflammatory and structural markers within the rumen epithelium during graininduced ruminal acidosis in lactating dairy cattle. Am. J. Animal Vet. Sci., 7: 141-148. DOI: 10.3844/ajavsp.2012.141.148

Duffield, T., 1999. A fistful of rumen--a novel approach to rumen fistula surgery. Proceedings of the ... Annual Conference, (AC' 99), National Agricultural Library.

Eming, S.A., T. Krieg and J.M. Davidson, 2007. Inflammation in wound repair: molecular and cellular mechanisms. J. Invest. Dermatol., 127: 514525. DOI: $10.1038 /$ sj.jid.5700701

Eyler, C.E. and M.J. Telen, 2006. The Lutheran glycoprotein: a multifunctional adhesion receptor. Transfusion, 46: 668-677. DOI: 10.1111/j.15372995.2006.00779.x

Flo, T.H., K.D. Smith, S. Sato, D.J. Rodriguez and M.A. Holmes et al., 2004. Lipocalin 2 mediates an innate immune response to bacterial infection by sequestrating iron. Nature, 432: 917-921. DOI: 10.1038/nature03104

Gabel, G., J.R. Aschenbach and F. Muller, 2002. Transfer of energy substrates across the ruminal epithelium: Implications and limitations. Anim. Health Res. Rev., 3: 15-30. PMID: 12400867 
Gao, L., G. Joberty, I.G. Macara, 2002. Assembly of epithelial tight junctions is negatively regulated by Par6. Curr. Biol., 12: 221-225. PMID: 11839275

Garrett, E.F., M.N. Pereira, K.V. Nordlund, L.E. Armentano and W.J. Goodger et al., 1999. Diagnostic methods for the detection of subacute ruminal acidosis in dairy cows. J. Dairy Sci., 82: 1170-1178. DOI: $\quad 10.3168 / \mathrm{jds} . S 0022-$ 0302(99)75340-3

Gilmore, T.D., 2006. Introduction to NF-kappaB: players, pathways, perspectives. Oncogene, 25: 6680-6684. DOI: 10.1038/sj.onc. 1209954

Goodlad, R.A., 1981. Some effects of diet on the mitotic index and the cell cycle of the ruminal epithelium of sheep. Q J. Exp. Physiol., 66: 487-499. PMID: 6914682

Goto, A., K. Matsushita, V. Gesellchen, L. El Chamy and D. Kuttenkeuler et al., 2008. Akirins are highly conserved nuclear proteins required for NF-kappaBdependent gene expression in drosophila and mice. Nat. Immunol., 9: 97-104. DOI: 10.1038/ni1543

Gozho, G.N., J.C. Plaizier, D.O. Krause, A.D. Kennedy and K.M. Wittenberg, 2005. Subacute ruminal acidosis induces ruminal lipopolysaccharide endotoxin release and triggers an inflammatory response. J. Dairy Sci., 88: 1399-1403. DOI: 10.3168/jds.S0022-0302(05)72807-1

Grahammer, F., F. Artunc, D. Sandulache, R. Rexhepaj and B. Friedrich et al., 2006. Renal function of gene-targeted mice lacking both SGK1 and SGK3. Am. J. Physiol. Regul. Integr. Comp. Physiol., 290: R945-950. DOI: 10.1152/ajpregu.00484.2005

Gray, P.W., A.E. Corcorran, R.L.E. Jr., M.G., Byers and T.B. Shows, 1993. The genes for the Lipopolysaccharide Binding Protein (LBP) and the Bactericidal Permeability Increasing protein (BPI) are encoded in the same region of human chromosome 20. Genomics, 15: 188-190. DOI: 10.1006/geno.1993.1030

Guilloteau, P., L. Martin, V. Eeckhaut, R. Ducatelle and R. Zabielski et al., 2010. From the gut to the peripheral tissues: the multiple effects of butyrate. Nutr. Res. Rev., 23: 366-384. DOI: 10.1017/S0954422410000247

Guri, A.J., S.K. Mohapatra, W.T. Horne, R. Hontecillas and J. Bassaganya-Riera, 2010. The Role of T cell PPAR gamma in mice with experimental inflammatory bowel disease. BMC Gastroenterol 10, 60-60. DOI: 10.1186/1471-230X-10-60
Haataja, L., V. Kaartinen, J. Groffen and N. Heisterkamp, 2002. The small GTPase Rac3 interacts with the integrin-binding protein CIB and promotes integrin alpha (IIb)beta(3)-mediated adhesion and spreading. J. Biol. Chem., 277: 83218328. PMID: 11756406

Haegeman, G., 2003. Inhibition of signal transduction pathways involved in inflammation. Eur. Respir. J. Suppl., 44: 16s-19s. PMID: 14582894

Hamer, H.M., D. Jonkers, K. Venema, S. Vanhoutvin and F.J. Troost et al., 2008. Review article: The role of butyrate on colonic function. Aliment Pharmacol. Ther., 27: 104-119. DOI: 10.1111/j.13652036.2007.03562.x

Hao, H., K. Iihara, H. Ishibashi-Ueda, F. Saito and S. Hirota, 2011. Correlation of thin fibrous cap possessing adipophilin-positive macrophages and intraplaque hemorrhage with high clinical risk for carotid endarterectomy. J. Neurosurg., 114: 10801087. PMID: 20887090

Hatziapostolou, M., G. Koukos, C. Polytarchou, F. Kottakis and O. Serebrennikova et al., 2011. Tumor progression locus 2 mediates signal-induced increases in cytoplasmic calcium and cell migration. Sci. Signal., 4: ra55-ra55. PMID: 21868363

Henrikson, R.C. and B.D. Stacy, 1971. The barrier to diffusion across ruminal epithelium: a study by electron microscopy using horseradish peroxidase, lanthanum and ferritin. J. Ultrastruct. Res., 34: 7282. PMID: 5539912

Hoffmann, A. and D. Baltimore, 2006. Circuitry of nuclear factor kappaB signaling. Immunol. Rev., 210: 171-186. PMID: 16623771

Huuskonen, J., T. Suuronen, T. Nuutinen, S. Kyrylenko and A. Salminen, 2004. Regulation of microglial inflammatory response by sodium butyrate and short-chain fatty acids. Br. J. Pharmacol., 141: 874880. PMID: 14744800

Janmohamed, A., C.T. Dolphin, I.R. Phillips and E.A. Shephard, 2001. Quantification and cellular localization of expression in human skin of genes encoding flavin-containing monooxygenases and cytochromes P450. Biochem. Pharmacol., 62: 777786. PMID: 11551524

Jobin, C. and R.B. Sartor, 2000a. The I kappa B/NFkappa B system: A key determinant of mucosalinflammation and protection. Am. J. Physiol. Cell. Physiol., 278: C451-C462. PMID: 10712233

Jobin, C. and R.B. Sartor, 2000b. NF-kappaB signaling proteins as therapeutic targets for inflammatory bowel diseases. Inflamm. Bowel. Dis., 6: 206-213. PMID: 10961593 
Johnson, R.W., 1997. Inhibition of growth by proinflammatory cytokines: an integrated view. J. Anim. Sci., 75: 1244-1255. PMID: 9159271

Kaiser, S., P. Schirmacher, A. Philipp, M. Protschka and I. Moll et al., 1998. Induction of bone morphogenetic protein-6 in skin wounds. Delayed reepitheliazation and scar formation in BMP-6 overexpressing transgenic mice. J. Invest. Dermatol., 111: 1145-1152. PMID: 9856831

Keunen, J.E., J.C. Plaizier, L. Kyriazakis, T.F. Duffield and T.M. Widowski et al., 2002. Effects of a subacute ruminal acidosis model on the diet selection of dairy cows. J. Dairy. Sci., 85: 33043313. PMID: 12512604

Khafipour, E., D.O. Krause and J.C. Plaizier, 2009a. Alfalfa pellet-induced subacute ruminal acidosis in dairy cows increases bacterial endotoxin in the rumen without causing inflammation. J. Dairy. Sci., 92: 1712-1724. DOI: 10.3168/jds.2008-1656

Khafipour, E., D.O. Krause and J.C. Plaizier, 2009b. A grain-based subacute ruminal acidosis challenge causes translocation of lipopolysaccharide and triggers inflammation. J. Dairy Sci., 92: 1060-1070. DOI: $10.3168 /$ jds.2008-1389

Kinoshita, M., Y. Suzuki and Y. Saito, 2002. Butyrate reduces colonic paracellular permeability by enhancing PPARgamma activation. Biochem. Biophys. Res. Commun., 293: 827-831. PMID: 12054544

Kleen, J.L., G.A. Hooijer, J. Rehage and J.P. Noordhuizen, 2003. Subacute ruminal acidosis (SARA): A review. J. Vet. Med. A Physiol. Pathol. Clin. Med., 50: 406-414. PMID: 14633219

Kristensen, N.B., A. Danfaer and N. Agergaard, 1998. Absorption and metabolism of short-chain fatty acids in ruminants. Arch. Tierernahr., 51: 165-175. PMID: 9672714

Kumar, A., Y. Takada, A.M. Boriek and B.B. Aggarwal, 2004. Nuclear factor-kappaB: its role in health and disease. J. Mol. Med., 82: 434-448. PMID: 15175863

Kuratomi, G., A. Komuro, K. Goto, M. Shinozaki and K. Miyazawa et al., 2005. NEDD4-2 (neural precursor cell expressed, developmentally down-regulated 42) negatively regulates TGF-beta (transforming growth factor-beta) signalling by inducing ubiquitinmediated degradation of Smad2 and TGF-beta type I receptor. Biochem. J., 386: 461-470. PMID: 15496141

Lebrun, J.J., K. Takabe, Y. Chen and W. Vale, 1999. Roles of pathway-specific and inhibitory Smads in activin receptor signaling. Mol. Endocrinol., 13: 1523. PMID: 9892009
Lee, J.C., O. Schickling, A.H. Stegh, R.G. Oshima and D. Dinsdale et al., 2002. DEDD regulates degradation of intermediate filaments during apoptosis. J. Cell. Biol., 158: 1051-1066. PMID: 12235123

Li, M.O., Y.Y. Wan, S. Sanjabi, A.K. Robertson and R.A. Flavell, 2006. Transforming growth factor-beta regulation of immune responses. Annu. Rev. Immunol., 24: 99-146. PMID: 16551245

Li, S., E. Khafipour, D.O. Krause, A. Kroeker and J.C. Rodriguez-Lecompte et al., 2012. Effects of subacute ruminal acidosis challenges on fermentation and endotoxins in the rumen and hindgut of dairy cows. J. Dairy Sci., 95: 294-303. PMID: 22192209

Li, S., L. Wang, M. Berman, Y.Y. Kong and M.E. Dorf, 2011. Mapping a dynamic innate immunity protein interaction network regulating type I interferon production. Immunity, 35: 426-440. PMID: 21903422

Lin, H.V., A. Frassetto, E.J.K. Jr., A.R. Nawrocki and M.M. Lu et al., 2012. Butyrate and propionate protect against diet-induced obesity and regulate gut hormones via free fatty acid receptor 3-independent mechanisms. PLoS One, 7: e35240- e35240. PMID: 22506074

Luo, D., F.M. Szaba, L.W. Kummer, E.F. Plow and N. Mackman et al., 2011. Protective roles for fibrin, tissue factor, plasminogen activator inhibitor-1 and thrombin activatable fibrinolysis inhibitor, but not factor XI, during defense against the gram-negative bacterium Yersinia enterocolitica. J. Immunol., 187: 1866-1876. PMID: 21724997

Lykos, T., G.A. Varga and D. Casper, 1997. Varying degradation rates of total nonstructural carbohydrates: Effects on ruminal fermentation, blood metabolites and milk production and composition in high producing Holstein cows. J. Dairy Sci., 80: 3341-3355. PMID: 9436117

Martin Jr. D.W. and E.W. Gelfand, 1981. Biochemistry of diseases of immunodevelopment. Annu. Rev. Biochem., 50: 845-877. PMID: 6267992

Mattos, K.A., H. D'Avila, L.S. Rodrigues, V.G. Oliveira and E.N. Sarno et al., 2010. Lipid droplet formation in leprosy: Toll-like receptor-regulated organelles involved in eicosanoid formation and mycobacterium leprae pathogenesis. J. Leukoc. Biol., 87: 371-384. PMID: 19952355

Meazza, C., S. Pagani, P. Travaglino and M. Bozzola, 2004. Effect of Growth Hormone $(\mathrm{GH})$ on the immune system. Pediatr. Endocrinol. Rev. Suppl., 3: 490-495. PMID: 16444180 
Miyoshi, J., T. Higashi, H. Mukai, T. Ohuchi and T. Kakunaga, 1991. Structure and transforming potential of the human cot oncogene encoding a putative protein kinase. Mol. Cell. Biol., 11: 40884096- PMID: 2072910

Miyoshi, M., H. Sakaki, M. Usami, N. Iizuka and K. Shuno et al., 2011. Oral administration of tributyrin increases concentration of butyrate in the portal vein and prevents lipopolysaccharide-induced liver injury in rats. Clin. Nutr., 30: 252-258. PMID: 21051124

Morikawa, A., T. Sugiyama, N. Koide, I. Mori and M.M. $\mathrm{Mu}$ et al., 2004. Butyrate enhances the production of nitric oxide in mouse vascular endothelial cells in response to gamma interferon. J. Endotoxin. Res., 10: 32-38. PMID: 15025822

Motoi, Y., T. Oohashi, H. Hirose, M. Hiramatsu and S. Miyazaki et al., 1993. Turbidimetric-kinetic assay of endotoxin in rumen fluid or serum of cattle fed rations containing various levels of rolled barley. $\mathrm{J}$. Vet. Med. Sci., 55: 19-25. PMID: 8461422

Muta, T. and K. Takeshige, 2001. Essential roles of CD14 and lipopolysaccharide-binding protein for activation of Toll-Like Receptor (TLR) 2 as well as TLR4 Reconstitution of TLR2- and TLR4-activation by distinguishable ligands in LPS preparations. Eur. J. Biochem., 268: 4580-4589. PMID: 11502220

Ni, Y.F., J.Wang, X.L. Yan, F. Tian and J.B. Zhao et al., 2010. Histone deacetylase inhibitor, butyrate, attenuates lipopolysaccharide-induced acute lung injury in mice. Respir. Res., 11: 33-33. PMID: 20302656

Norambuena, A. and M.A. Schwartz, 2011. Effects of integrin-mediated cell adhesion on plasma membrane lipid raft components and signaling. Mol. Biol. Cell., 22: 3456-3464. PMID: 21795400

Ong, C.T., Y.T. Khoo, A. Mukhopadhyay, D.V. Do and I.J. Lim et al., 2007. mTOR as a potential therapeutic target for treatment of keloids and excessive scars. Exp. Dermatol., 16: 394-404. PMID: 17437482

Ong, S.H., G.R. Guy, Y.R. Hadari, S. Laks and N. Gotoh et al., 2000. FRS2 proteins recruit intracellular signaling pathways by binding to diverse targets on fibroblast growth factor and nerve growth factor receptors. Mol. Cell. Biol., 20: 979-989. PMID: 10629055

Pendas, A.M., M. Balbin, E. Llano, M.G. Jimenez and C. Lopez-Otin, 1997. Structural analysis and promoter characterization of the human collagenase-3 gene (MMP13). Genomics, 40: 222-233. PMID: 9119388
Pendas, A.M., I. Santamaria, M.V. Alvarez, M. Pritchard and C. Lopez-Otin, 1996. Fine physical mapping of the human matrix metalloproteinase genes clustered on chromosome 11q22.3. Genomics, 37: 266-268. PMID: 8921407

Penner, G.B., J.R. Aschenbach, G. Gabel, R. Rackwitz and M. Oba, 2009a. Epithelial capacity for apical uptake of short chain fatty acids is a key determinant for intraruminal $\mathrm{pH}$ and the susceptibility to subacute ruminal acidosis in sheep. J. Nutr., 139: 1714-1720. PMID: 19640964

Penner, G.B., K.A. Beauchemin and T. Mutsvangwa, 2007. Severity of ruminal acidosis in primiparous holstein cows during the periparturient period. J. Dairy Sci., 90: 365-375. PMID: 17183105

Penner, G.B., M. Taniguchi, L.L. Guan, K.A. Beauchemin and M. Oba, 2009b. Effect of dietary forage to concentrate ratio on volatile fatty acid absorption and the expression of genes related to volatile fatty acid absorption and metabolism in ruminal tissue. J. Dairy Sci., 92: 2767-2781. PMID: 19448011

Perez, B.H. and I.K. Gipson, 2008. Focus on Molecules: human mucin MUC16. Exp. Eye. Res., 87: 400-401. PMID: 18289532

Perkins, N.D., 2007. Integrating cell-signalling pathways with NF-kappaB and IKK function. Nat. Rev. Mol. Cell. Biol., 8: 49-62. PMID: 17183360

Pfaffl, M.W., A. Tichopad, C. Prgomet and T.P. Neuvians, 2004. Determination of stable housekeeping genes, differentially regulated target genes and sample integrity: BestKeeper--Excelbased tool using pair-wise correlations. Biotechnol. Lett., 26: 509-515. PMID: 15127793

Plaizier, J.C., D.O. Krause, G.N. Gozho and B.W. McBride, 2008. Subacute ruminal acidosis in dairy cows: the physiological causes, incidence and consequences. Vet. J. 176: 21-31. PMID: 18329918

Reiner, A., D. Yekutieli and Y. Benjamini, 2003. Identifying differentially expressed genes using false discovery rate controlling procedures. Bioinformatics, 19: 368-375. PMID: 12584122

Roediger, W.E., 1990. The starved colon--diminished mucosal nutrition, diminished absorption and colitis. Dis. Colon. Rectum., 33: 858-862. PMID: 2209275

Ross, J.A., A.G. Moses, K.C. Fearon, 1999. The anticatabolic effects of n-3 fatty acids. Curr. Opin. Clin. Nutr. Metab. Care, 2: 219-226. PMID: 10456251

Sarbassov, D.D., S.M. Ali, D.H. Kim, D.A. Guertin and R.R. Latek et al., 2004. Rictor, a novel binding partner of mTOR, defines a rapamycin-insensitive and raptor-independent pathway that regulates the cytoskeleton. Curr. Biol., 14: 1296-1302. PMID: 15268862 
SAS, 2004. SAS/STAT 9.1: User's Guide. 1st Edn., SAS Institute, ISBN-10: 1590472438, pp: 4420.

Schmidt-Ott, K.M., K. Mori, J.Y. Li, A. Kalandadze and D.J. Cohen et al., 2007. Dual action of neutrophil gelatinase-associated lipocalin. J. Am. Soc. Nephrol., 18: 407-413. PMID: 17229907

Schreml, S., R.M. Szeimies, L. Prantl, M. Landthaler and P. Babilas, 2010. Wound healing in the 21st century. J. Am. Acad. Dermatol., 63: 866-881. PMID: 20576319

Segain, J.P., D.R.D.L. Bletiere, A. Bourreille, V. Leray and N. Gervois et al., 2000. Butyrate inhibits inflammatory responses through NFkappaB inhibition: implications for Crohn's disease. Gut., 47: 397-403. PMID: 10940278

Sigal, L.H., 2006. Basic science for the clinician 39: NFkappaB-function, activation, control, and consequences. J. Clin. Rheumatol., 12: 207-211. PMID: 16891930

Steele, M.A., J. Croom, M. Kahler, O. AlZahal and S.E. Hook et al., 2011a. Bovine rumen epithelium undergoes rapid structural adaptations during graininduced subacute ruminal acidosis. Am. J. Physiol. Regul. Integr. Comp. Physiol., 300: 1515-1523. PMID: 21451145

Steele, M.A., L. Dionissopoulos, O. AlZahal, J. Doelman and B.W. McBride, 2012. Rumen epithelial adaptation to ruminal acidosis in lactating cattle involves the coordinated expression of insulin-like growth factor-binding proteins and a cholesterolgenic enzyme. J. Dairy Sci., 95: 318-327. PMID: 22192211

Steele, M.A., G. Vandervoort, O. AlZahal, S.E. Hook and J.C. Matthews et al., 2011b. Rumen epithelial adaptation to high-grain diets involves the coordinated regulation of genes involved in cholesterol homeostasis. Physiol. Genomics, 43: 308-316. PMID: 21245418

Steinert, P.M., D.A. Parry and L.N. Marekov, 2003. Trichohyalin mechanically strengthens the hair follicle: Multiple cross-bridging roles in the inner root shealth. J. Biol. Chem., 278: 41409-41419. PMID: 12853460

Suuronen, T., J. Huuskonen, R. Pihlaja, S. Kyrylenko and A. Salminen, 2003. Regulation of microglial inflammatory response by histone deacetylase inhibitors. J. Neurochem, 87: 407-416. PMID: 14511118

Suzuki, A., T. Yamanaka, T. Hirose, N. Manabe and K. Mizuno et al., 2001. Atypical protein kinase $\mathrm{C}$ is involved in the evolutionarily conserved par protein complex and plays a critical role in establishing epithelia-specific junctional structures. J. Cell. Biol., 152: 1183-1196. PMID: 11257119
Tan, N.S., G. Icre, A. Montagner, B. Bordier-TenHeggeler and W. Wahli et al., 2007. The nuclear hormone receptor peroxisome proliferator-activated receptor beta/delta potentiates cell chemotactism, polarization and migration. Mol. Cell. Biol., 27: 7161-7175. PMID: 17682064

Tanabe, M. and M. Kanehisa, 2012. Using the KEGG database resource. Curr. Protoc. Bioinformatics. PMID: 22700311

Taniguchi, Y., H. Ido, N. Sanzen, M. Hayashi and R. Sato-Nishiuchi et al., 2009. The C-terminal region of laminin beta chains modulates the integrin binding affinities of laminins. J. Biol. Chem., 284: 7820-7831. PMID: 19147489

Thibault, R., F. Blachier, B. Darcy-Vrillon, P. De Coppet and A. Bourreille et al., 2010. Butyrate utilization by the colonic mucosa in inflammatory bowel diseases: a transport deficiency. Inflamm. Bowel. Dis., 16: 684-695. PMID: 19774643

Totzke, G., F. Essmann, S. Pohlmann, C. Lindenblatt and R.U. Janicke et al., 2006. A novel member of the IkappaB family, human IkappaB-zeta, inhibits transactivation of p65 and its DNA binding. J. Biol. Chem., 281: 12645-12654. PMID: 16513645

Tsuchida, K., M. Nakatani, T. Matsuzaki, N. Yamakawa and Z. Liu et al., 2004. Novel factors in regulation of activin signaling. Mol. Cell. Endocrinol., 225: 18. PMID: 15451561

Berghe, V.W., L. Vermeulen, P. Delerive, K. De Bosscher and B. Staels et al., 2003. A paradigm for gene regulation: Inflammation, NF-kappaB and PPAR. Adv. Exp. Med. Biol., 544: 181-196. PMID: 14713228

Wallace, J.L., 2008. Prostaglandins, NSAIDs and gastric mucosal protection: Why doesn't the stomach digest itself? Physiol. Rev., 88: 1547-1565. PMID: 18923189

Wang, S.J., W.J. Liu, L.G. Yang, C.A. Sargent and H.B. Liu et al., 2012. Effects of FUT1 gene mutation on resistance to infectious disease. Mol. Biol. Rep., 39: 2805-2810. PMID: 21695432

Williamson, D.H., H.A. Krebs and J. Mellanby, 1962. Enzymic determination of D(-)-beta-hydroxybutyric acid and acetoacetic acid in blood. Biochemical J., 82: 90-90. PMID: 14007241

Wilson, D.K., F.B. Rudolph and F.A. Quiocho, 1991. Atomic structure of adenosine deaminase complexed with a transition-state analog: understanding catalysis and immunodeficiency mutations. Sci., 252: 1278-1284. PMID: 1925539 
Wu, Y., W. Li, C. Zhou, F. Lu and T. Gao et al., 2012. Ketamine inhibits lipopolysaccharide-induced astrocytes activation by suppressing TLR4/NF-kB pathway. Cell. Physiol. Biochem., 30: 609-617. PMID: 22832327

Xue, Y., S.F. Liao, K.W. Son, S.L. Greenwood and B.W. McBride et al., 2010. Metabolic acidosis in sheep alters expression of renal and skeletal muscle amino acid enzymes and transporters. J. Anim. Sci., 88: 707-717. PMID: 19820050

Yamanaka, T., Y. Horikoshi, Y. Sugiyama, C. Ishiyama and A. Suzuki et al., 2003. Mammalian Lgl forms a protein complex with PAR-6 and aPKC independently of PAR-3 to regulate epithelial cell polarity. Curr. Biol., 13: 734-743. PMID: 12725730

Yan, X.M., J. Ren, Y.M. Guo, N.S. Ding and K.F. Chen et al., 2003. Research on the genetic variations of a1-fucosytransferase (FUT1) gene in 26 pig breeds. Yi Chuan. Xue. Bao., 30: 830-834. PMID: 14577374
Zebeli, Q. and B.N. Ametaj, 2009. Relationships between rumen lipopolysaccharide and mediators of inflammatory response with milk fat production and efficiency in dairy cows. J. Dairy Sci., 92: 38003809. PMID: 19620662

Zhang, S.Z., X.H. Zhao and D.C. Zhang, 2006. Cellular and molecular immunopathogenesis of ulcerative colitis. Cell. Mol. Immunol., 3: 35-40. PMID: 16549047

Zhang, Y., L. Zhou, Y.L. Bao, Y. Wu and C.L. Yu et al., 2010. Butyrate induces cell apoptosis through activation of JNK MAP kinase pathway in human colon cancer RKO cells. Chem. Biol. Interact., 185: 174-181. PMID: 20346929

Zhou, T., 2013. Computational Reconstruction of Metabolic Networks from KEGG. Methods Mol. Biol., 930: 235-249. PMID: 23086844 